\title{
HELLENISTIC AND ROMAN UNGUENTARIA FROM THE NECROPOLIS OF TRALLEIS
}

\begin{abstract}
Aslı SARAÇOĞLU*
Keywords: Tralleis $・$ Necropolis $・$ Unguentarium $・$ Tomb

Abstract: The material discussed here was found in the western necropolis area during the 2007 excavation campaign in Tralleis. According to the analysis of the findings, the western necropolis was in use from the late $4^{\text {th }}$ century B.C. until the second half of the $4^{\text {th }}$ century A. D. The earliest unguentaria noted from the Tralleis dates from around the third quarter of the $4^{\text {th }}$ century B.C. The clay of the Tralleis unguentaria always contains some amount of mica. Clay and slip colors vary between 2.5 YR $7 / 4$, 5YR 6/6 or 5YR 7/3-4 according to Munsell Catalogue. Form and workmanship reflect general characteristics of the Anatolian customs. Tralleis unguentaria are non-decorated and the majority of them were not carefully made. All of them are handleless. Most of them have been found intact or only partially damaged. One of the most important forms in the classification is the fusiform unguentaria and they are similar to the western Anatolian examples with their characteristic features. Forms of these examples can also be compared with the finds from the other contemporary settlements and contexts. Most of them are similar to examples from the $1^{\text {st }}$ and $2^{\text {nd }}$ centuries B.C with their long, thin forms and spindle-shaped bodies. The second group consists of twelve bulbous unguentaria. The majority of these samples have long necks, rounded bodies, and flat bases. In terms of technique and form, all of these examples are Roman products. This type of unguentarium was commonly found in most of the Mediterranean cities.
\end{abstract}

\section{TRALLEIS NEKROPOLÜNDEN HELLENISTIIK VE ROMA DÖNEMİ UNGUENTARIUMLARI}

\author{
Anabtar Kelimeler: Tralleis $\bullet$ Nekropolis $\bullet$ Unguentarium $\bullet$ Mezar
}

Özet: Burada ele alınan malzeme, Tralleis'de 2007 yılı kazı çalışmalarında batı nekropolis alanında bulunmuştur. Ele geçen eserler 1şı̆̆ında, batı nekropolis alanının MÖ 4. yüzyıl sonlarından MS 4. yüzyılın ikinci yarısına kadar kullanıldığı anlaşılmaktadır. Tralleis'de bulunan en erken unguentariumlar yaklaşık olarak MÖ 4. yüzyllın üçüncü çeyreğine tarihlenmektedir. Tralleis unguentariumlarının hamuru her zaman için bir miktar mika içermektedir. Hamur ve astar Munsell Kataloğu'na göre 2.5YR 7/4, 5YR 6/6 ve 5YR 7/3-4 renkleri arasında değişir. Form ile işçilik Anadolu geleneklerinin genel özelliklerini yansıtır. Tralleis unguentariumları bezemesizdir ve çoğunluğu özenli bir işçilik göstermez. Örneklerin tamamı kulpsuzdur. Büyük çoğunluğu sağlam ya da az hasarlı bulunmuştur. Sınıflandırmada en önemli formlardan biri iğ gövdeli unguentariumlardır ve genel özellikleri ile Batı Anadolu örnekleri ile benzeşir. Bu örneklerin formları diğer çağdaş merkezler ve kontekstlerdeki buluntularla karşılaştırılabilir. Bunların büyük çoğunluğu uzun ince formları ve iğ biçimli gövdeleriyle, MÖ 2. ve 1. yüzyll örnekleriyle benzeşir. İkinci grubu 12 örnekle soğan gövdeli unguentariumlar oluşturur. Bu örneklerin çoğunluğu uzun boyunlu, yuvarlak gövdeli ve düz tabanlıdır. Teknik ve form açısından bu örneklerin tamamı Roma üretimidir. Unguentariumların bu tipi birçok Akdeniz kentinde bulunmuştur.

*Assoc. Prof. Dr. Ash Saraçoğlu, Adnan Menderes University, Faculty of Arts and Sciences, Department of Archaeology, Aytepe Kampü̈ü AYDIN / TURKEY, e-mail: saracogluasli@gmail.com 
The material discussed here includes all the significant pieces of the Hellenistic and Roman unguentaria found during the excavation of the western necropolis in 2007 at Tralleis ${ }^{1}$. As seen in other centers of Anatolia, the majority of Tralleis samples are grave gifts.

The materials uncovered from western necropolis area during the 2007 excavations campaign have made a valuable contribution to our knowledge regarding unguentaria form and chronology in Tralleis during the Hellenistic and Roman periods.

The ancient city of Tralleis (modern Aydin) is situated on a plateau at the southern slope of Mount Messogis. Thanks to her strategic position and geographical location, she became the stage for many important events throughout the history. During her long history, Tralleis has frequently been regarded as the artistic capital of Anatolia. The city is commonly recognized as one of the major centers thanks to its art, especially in the Hellenistic Age. It is known that Tralleis was an important sculpture center in the Hellenistic and Roman periods $^{2}$. Besides, recent works and ancient sources have shown that Tralleis was an important place in ceramic production as well as sculpture. Additionally, Tralleis

1 I thank Prof. Dr. Abdullah Yaylali, the director of the Tralleis excavation campaigns during 2006-2008, for permitting me to work on the materials found in Tralleis western necropolis. The preliminary reports of Tralleis excavation 2007 campaign have been published (Yaylalı 2009, 17-40). I also would like to thank Prof. Dr. Yaşar İşcan and his team for studying and reorganizing the human skeletal materials in the tombs.

2 See also: Özgan 1982, 1 ff. was one of the important centers of Eastern Sigillata B production ${ }^{3}$.

\section{Excavations}

The western necropolis area of Tralleis has been only partially excavated. Therefore, the chronology and stratification of this area remain uncertain but in 2007 a total of 50 tombs had been revealed. Among the above mentioned tombs, there were tile graves containing adults in extended position, sarcophagi, the grave stele of a gladiator, amphora graves, urns containing cremated bones, and pithoi in which children were buried. The earliest burials encountered in 2007 belong to the late $4^{\text {th }}$ century B.C.

In Tralleis, cremation burials with grave offerings are usually observed more for the early Roman period. Yet, inhumation graves with grave deposits were especially common during the late Roman period in tile-covered graves ${ }^{4}$. The unguentaria in most of the graves are the characteristics of the Hellenistic and Roman burials, but their types do not clearly exhibit differences between male and female burials. In spite of the existence of pottery in most of the tile-covered graves of the late Roman period in Tralleis, no unguentaria have been encountered.

3 The view that Tralleis was the production center of Eastern Sigillata B was supported by ancient authors and recent studies: Plin. nat. XXXV, 46; Hayes 1972, 9-10; Erol 2004, 1 ff; Takaoğlu 2006, 263-265; Civelek 2008, $57 \mathrm{ff}$.

4 The 2007 campaign in Tralleis necropolis revealed a concentration of 19 inhumations from the late Roman period, most probably died from different causes. All of them are adults but one dog. Among the adults there are both males and females. Also coins were notable finds in the tile graves. The earliest coins are from the Constantinus II period (337340), the majority from Constantius II (337-361) and from Constans (337-350). 
What was a major and quite astonishing result of the 2007 Tralleis excavation is the discovery of an undisturbed chamber tomb with a dromos. The chamber tomb is a typical example of the klinai tombs in Anatolian necropoleis and appears to contain rich finds in its two chambers. There is no certain data regarding the stratigraphy of this tomb context; it includes the usual mixture of various finds, which consist of Hellenistic and Roman terracotta figurines, glass, lamps, metal objects, a few jewellery and ceramics. The findings stated above are more or less standard, with local characteristics for each of the other necropoleis in Anatolia.

\section{Findings}

Unguentaria are the most common finds in the chamber tomb in Tralleis. This article contains a total of 47 different forms of unguentaria but over 60 unguentaria were found in well-dated deposits during the 2007 excavation campaign in Tralleis, of which, 46 came from the chamber tomb with dromos. These materials are particularly useful for they are well preserved and reflect characteristic forms ${ }^{5}$. Tralleis unguentaria were found in both cremation and inhumation graves. As known, and just like in Tralleis, the majority of the Hellenistic findings from the tomb excavation consist of various fusiform unguentaria, which were popular

\footnotetext{
As known, grave gifts represent an important episode in Greek and Roman pottery. The finds from the graves are crucial for establishing ceramic chronology, burial customs and local pottery production. Excavations in the western necropolis in 2007 provided significant evidence for some changes in the community life, or at least some substantial change in customs and regarding ceramics development from the early Hellenistic period until the early Roman period.
}

during that period. However, detailed analysis of the Tralleis unguentaria has indicated that the chamber tomb not only contains a large deposit of Hellenistic materials, but also some bulbous examples dating to the early Roman period.

There are various hypotheses to explain the existence of unguentaria in the burial sites in the ancient Mediterranean'. They could be used as grave offerings, or represent a part of libations conducted during funerary ceremonies ${ }^{7}$. Unguentaria were also a part of the funerary ritual, to some extent, because perfume was used in funerary rites; accordingly they were a suitable grave gift ${ }^{8}$. The presence of the unguentaria in the Hellenistic graves may indicate a revival of an earlier practice that replaced the aryballoi in the 6th century and the small lekythoi in $5^{\text {th }}$ and early $4^{\text {th }}$ century burials used for storing perfume or oil for the dead ${ }^{9}$.

6 The earliest examples from Spain belong to the early to mid-5 $5^{\text {th }}$ century B.C. Also, the early examples from Eastern Mediterranean can be dated to the late $4^{\text {th }}$ century B.C: (Agora XXII, 108; Anderson-Stojanović 1987, 108).

Anderson-Stojanović 1987, 122; Stern 2008, 291.

8 Unguentaria have double role in both life and death. It is known that unguentaria are found frequently in Hellenistic and Roman sites, especially in cemeteries (Boulter 1963, pp. 125-126, Schlörb-Vierneisel 1966, pp. 94-110, Agora XXXIII, 139). At the same time, the most common use of unguentaria probably was as a container and carrier of dispending liquids and powdered substances such as oil, perfume, cream, honey, vinegar, emulsion, fish sauce (Daremberg - Saglio 1963, 591; Labraunda II.1, 24; Toynbee 1971, 50. Anderson-Stojanović 1987, 107 108). We know that a huge variety of the Mediterranean plants produced essential oils in the ancient periods.

9 The unguentaria are believed to have replaced the lekythos in grave deposits by the end of the $4^{\text {th }}$ century B.C (Thompson 1934, 335, Fig.15, B6 and B7; Tarsus I, 171; Labraunda II.1, 25; Kurtz - Boardman 1971, 164 ff; Khairy 1980, 85; Heimberg 1982, 26; 
The product center and origin of unguentaria, in fact, were unknown. Their manufacture was very widespread and they were distributed throughout the Mediterranean, from Palestine to Spain in the Hellenistic and early Roman sites ${ }^{10}$. The earliest examples and production centers were accepted as Spain ${ }^{11}$, Syria ${ }^{12}$, Egypt $^{13}$, Cyprus $^{14}$, Rhodes ${ }^{15}$ and Athens ${ }^{16}$. The chronological development and distribution of the unguentaria can be traced back to the Hellenistic and Roman centers in Anatolia. Many examples were found in Tarsus ${ }^{17}$, Metropolis ${ }^{18}$, Tralleis ${ }^{19}$, Ephesos $^{20}$, Miletos $^{21}$, Labraunda ${ }^{22}$, Pata$\mathrm{ra}^{23}$, Stratonikeia ${ }^{24}$, Knidos ${ }^{25}$, Kaunos ${ }^{26}$, Kelenderis $^{27}$, Laodikeia ${ }^{28}$, and Sardeis ${ }^{29}$ in Anatolia.

Pemberton 1985, 284; Anderson-Stojanović 1987, 106; Berlin 1997, 58; Samothrace 11, 798).

10 Anderson-Stojanović 1987, 105.

11 Forti 1962, 143-157.

12 In Thompson's opinion, the origin of the gray unguentaria of Athens is Syria: Thompson 1934, 474, fn. 4; see also Myres 1914, 120; Vessberg - Westholm 1956, 73.

13 Tarsus I, 171, fn. 63; Vessberg - Westholm 1956, 73 ff; Lapp 1961, 228; Labraunda II.1, 25, fn. 4.

14 Fusiform unguentaria at Cyprus appeared by the turn of the $4^{\text {th }}$ and $3^{\text {rd }}$ centuries B.C. (Thompson 1934, 472; Agora XII, 191 ff, Rotroff 1984, 258).

15 Guz-Zilberstein 1995, 304.

16 Thompson 1934, 473.

17 Tarsus I, 149-296.

18 Gürler 1994, 63-75.

19 Ölmez 2000; 27-43; Civelek 2001, 102-139.

20 FiE IX 2/2, 151, Lev. 206, O 1-2; Gassner 1997, 99, Lev. 347-349.

21 Pfrommer 1985, 58, 76, Lev. 52-53.

22 Labraunda II.1,23-28.

23 Dündar 2006, ff.

24 Baldiran 1999, 335-356.

25 Dotterweich 1999, 1 ff.

26 Schmaltz 1994, $231 \mathrm{ff}$.

27 Zoroğlu 1986, 455-464.

28 Şimşek - Duman 2007, 285-307.

29 Rotroff - Oliver 2003, 68, Lev. 43, No. 249.
Based on their technique and form, Tralleis unguentaria should be dated to between the late $4^{\text {th }}$ century B.C. and the late $1^{\text {st }}$ century A. D. The largest group of materials was found at trench I (Cat. Nos. 3-4, 6, 11-12, 32,36, 46-47) and kline 1 (Cat. Nos. 5, 16, 18-19, 22, 27-29, 33$35,39,45)$ in the chamber tomb. Nine unguentaria were found in kline 4 (Cat. Nos. 8, 14-15, 17, 26, 31, 40-41, 44), five in kline 3 (Cat. Nos. 20, 30, 38, 42-43), five in kline 5 (Cat. nos. 9-10, 23-25) and two in kline 2 (Cat. Nos. 21, 37). These findings should be contemporary products of the same workshops due to the evidence of graves in addition to the similarity of clay and shape.

\section{Typology}

The range of unguentaria types in Tralleis is not unusual. On the contrary, most of the forms are typical shapes of the Hellenistic and Roman periods. As known, the unguentaria were produced in two basic shapes; the fusiform with long tubular neck, downturned rim, spindleshaped body, cylindrical stem, small distinct ring foot and the bulbous shape with long neck, rounded body, and flat base. Both of these shapes occur in Tralleis although the bulbous outnumber the fusiform.

As shown by the studies, fusiform and bulbous shapes were in production clearly for a very long time with little change. However, shape is the primary and dominant consideration in the dating of both fusiform and bulbous unguenta$\mathrm{ria}^{30}$. The most popular unguentaria of the

\footnotetext{
30 A detailed description of forms and fabrics of the materials is given in the catalogue. The chronology of unguentaria given in the catalogue has been based
} 
Hellenistic period were the fusiform type. The shape that has come to be known as the fusiform unguentarium is found at the Hellenistic sites throughout the Mediterranean $^{31}$. At the same time, the fusiform unguentaria were in use for several centuries and the form indicates many variations. Furthermore, it appears that the fusiform unguentarium shape was not introduced into the Tralleis repertoire before the late $4^{\text {th }}$ century B.C.

Tralleis unguentaria are non-decorated and the majority of them were not carefully made. All of them are handleless. Majority of them have been found intact or only partially damaged. The range of colors is limited to 6 main categories in Tralleis. Red tones are found on most of them (light red, pale red, light reddish brown, reddish yellow), a few examples are made of pink (Cat. Nos. 13, 20, 30) and pinkish gray clay (Cat. No. 28).

All of the samples found in excavations can be of different profile and rate. Generally, unguentaria found in burials range from miniatures to large examples, with a height of 4-5 cm. and $20-30 \mathrm{~cm}$., respectively $^{32}$. The late Hellenistic unguentaria are of fairly thin clay. Tralleis unguentaria, however, fall within the range of 8 , 4- 26, $7 \mathrm{~cm}$. in height. In earlier pieces the walls are extremely thin but in the $2^{\text {nd }}$ and $1^{\text {st }}$ centuries this dimension rises. The earlier pieces have a very smooth texture and their surface has an iridescent sheen.

entirely on form comparisons with better datable examples from other parts of the ancient city.

31 Thompson 1934, 472-474; Labraunda II.1, 23-27; Bruneau 1970a, 58, Bruneau 1970b, 254; Hägg Fossey 1980, 29 ff, 72 ff, Pemberton 1985, 284-286; Anderson-Stojanović 1987, 105; Agora XXXIII, 137.

32 Anderson-Stojanović 1987, 106.
The early examples range in height from 10 to $15 \mathrm{~cm}$. and the diameter varies from 7 to $10 \mathrm{~cm}$.

Cat. Nos. 1 and 2 are the earliest and excellent examples and they can be dated to the third quarter of the $4^{\text {th }}$ century B.C (Figure 1, U1-U2). Cat. No. 1 is a piece of globular body, convex mouth, short neck, high shoulder, and small feet like those of 2, which both are also similar in clay and glaze. Two examples mentioned above are decorated with a red band on neck and shoulder ${ }^{33}$. Parallel examples can be dated to the late $4^{\text {th }}$ century B.C. ${ }^{34}$. The general shape of this form is to some extent related to the amphoriskos ${ }^{35}$. At the same time this profile of Figures 1 and 2 from Tralleis repertoire show connections with the lekythoi profile and similar examples of both of these shapes exist at Mylasa ${ }^{36}$. Besides, similar manufactures occur in other contexts of the third quarter of the $4^{\text {th }}$ century B.C., in Corinth ${ }^{37}$ and at Athenian Agora ${ }^{38}$.

Subsequent to foregoing, the pieces with globular body, short neck, high shoulder and conical ring base are Cat. Nos. 3-7 and 8 (Figure 1, U3-U8). On Cat. No. 6 the decoration of red lines is preserved around the bulging body (Figure 1, U6). Comparison with similar examples from the Athenian Agora ${ }^{39}, \mathrm{Ha}-$

\footnotetext{
3 Boulter 1963, 125; Pemberton 1985, 285; Hausmann 1996, 32, fn. 130.

34 Thompson 1934, 472.

35 Rotroff 1984, 258; Anderson-Stojanović 1987, 108.

36 Akarca 1952, 383 ff.

37 Corinth VII, Pl. 58, Figs. 585-586; Corinth XIII, Pl. 76. Figs. 10-11, Pl. 77, Fig. 16, Pl. 78, Fig. 7.

38 Agora XXIX, Pl. 85, Fig. 72, 1163-1167.

39 Thompson 1934, Fig. 15, B7; Anderson-Stojanović 1987, Fig. 2, Shape 1; Agora XXIX, Fig. 72, Pl. 85, 1168-1169.
} 
lae ${ }^{40}$, Cyprus $^{41}$, Corinth ${ }^{42}$, and Labraun$\mathrm{da}^{43}$ suggests a date in the early $3^{\text {td }}$ century B.C.

\section{Fusiform Unguentaria}

According to the preserved body form, at least thirty-five specimens are characteristic fusiform unguentaria and fall in Cat. Nos. 1-35 (Figure 1, U1-U12); (Figure 2, U13-U24); (Figure 3, U25U35). All of the examples reflect traditions of Anatolian forms and fabrics. Most of the Tralleis unguentaria have a long and thin form, with solid stems, similar to examples from the $2^{\text {nd }}$ century deposits (Figure 2, U14-U24); (Figure 3, U25-U32). The spindle-shaped body belongs to a form like that of unguentaria U9-U32, the traditional Hellenistic fusiform type from the $2^{\text {nd }}$ and $1^{\text {st }}$ century B.C. However, some of them are globular (Figure 1, U1-U8) or slender fusiform unguentaria (Figure 2, U13); (Figure 3, U25).

These are the most common and characteristic shape of the class, of which Cat. Nos. 9-32, being excellent instances in Tralleis. Cat. Nos. 14-24 found in the chamber tomb, represent the bestpreserved ones with a tall solid foot, a somewhat bulging body, and a tall neck (Figure 2, U14-U24). The rim and body profile of these examples have belonged to a traditional Hellenistic fusiform from the $2^{\text {nd }}-1^{\text {st }}$ centuries B.C.

Cat. Nos. 9-11 (Figure 1, U9-U11) are the smallest (H: 9, 4-9,8 cm), No. 27 (Figure 3, U27) is the biggest (H: 26, 7

40 Goldman 1940, Fig. 199, No. 16.

41 Vessberg - Westholm 1956, Fig. 24. 1.

42 Corinth VII, Pl. 58, Figs. 585-586; Corinth XIII, Pl. 76, Fig. 10-11; Pl. 77, Fig. 16; Pl. 78, Fig. 7.

43 Labraunda II.1, Pl. 12, No. 163. $\mathrm{cm})$ of all the fusiform unguentaria. Cat. Nos. 13, 14 and 15 can be dated to the early $2^{\text {nd }}$ century B.C. or a little later. Cat. Nos. 16-22 can be dated to the mid- $2^{\text {nd }}$ century B.C (Figure 2, U16-U22). Moreover, similar unguentaria occur in contexts of the mid- $2^{\text {nd }}$ century B.C., in Kerameikos $^{44}$, Athenian Agora ${ }^{45}$, Delos ${ }^{46}$, Pergamon $^{47}$, Labraunda ${ }^{48}$, Ephesos ${ }^{49}$, Metropolis $^{50}$, Eretria ${ }^{51}$ and Tarsus ${ }^{52}$.

Similar unguentaria of Cat. Nos. 9-15 are earlier than the middle of the $2^{\text {nd }}$ century B.C. These examples are probably to be dated to the second half or to the end of the $3^{\text {rd }}$ century B.C. Similar examples from Athenian Agora ${ }^{53}$ and Labraunda ${ }^{54}$ are dated to the same period. Shapes and details are also generally paralleled in other cities and the closest parallels for the types found in Tralleis are seen almost everywhere in Anatolia ${ }^{55}$.

\section{Bulbous Unguentaria}

The second group of materials in Tralleis consisted of twelve Roman bulbous unguentaria (Cat. Nos. 36-47 may well belong to the same form and shape; Figure 3, U36, Figure 4, U37-U47). Eventually the fusiform unguentaria were re-

44 Kerameikos IX, Taf. 69, No. 390.

45 Agora XXIX, Pl. 85, No. 1170.

46 Bruneau 1970b, 507.

47 AvP XII, Lev. 7, No. 9-15.

48 Labraunda II.1, P. 12, No. 174.

49 FiE IX 2/2, Taf. 211 017, Taf. 212018.

50 Gürler 1994, Lev. 29, 137-141.

51 Metzger 1969, Taf. 28, No. II.

52 Tarsus I, Fig. 135, No. 234.

53 Thompson 1934, Fig. 52, C 76; Agora XXIX, Fig. 72, Pl. 85, 1171.

54 Labraunda II.1, Pl. 12, No. 165.

55 Metropolis (Gürler 1994, Lev. 26, 125-128); Stratonikeia (Baldıran 1999, 338, Çiz. 1-9); Hierapolis (Okunak 2005, Cat. Nos. 2-3); Patara (Dündar 2006, U101). 
placed by footless body and the rounded or pear-shaped bulbous unguentaria, well known from deposits and burials of the second half of the $1^{\text {st }}$ century B.C. and is characteristic of the Roman era, particularly the early principate ${ }^{56}$.

Bulbous unguentaria found at Tralleis are probably local or regional products. According to the technique and form, most of them are Roman products $\left(1^{\text {st }}\right.$ century A.D or later). This type of unguentarium was commonly found in many Mediterranean cities and are associated with the burials and other contexts of the $1^{\text {st }}$ and well of the $2^{\text {nd }}$ century A. $\mathrm{D}^{57}$. The earliest specimens, however, appear in the second half of the $1^{\text {st }}$ century B.C. The bulbous shape appears at Corinth in Roman graves dated to shortly after 44 B.C and similar bulbous unguentaria from Israel and Jordan are dated to the same period $^{58}$. The early examples from Athenian Agora can be dated to the late $1^{\text {st }}$ century B.C. Tarsus examples were dated to ca. $150-50$ B.C. ${ }^{59}$.

In the earlier bulbous profile, an immediate expansion exists above the foot. These shapes are the ones, which must have been the most common during early Roman period. Cat. No. 36 is the earliest example from Tralleis and belongs to the early $1^{\text {st }}$ century A.D (Figure 3, U36).

56 Agora XXXIII, 156. For a good illustration of the shapes see Thompson 1971, 37. The bulbous shape is found at many Mediterranean cities in well-dated burials and other contexts for late first century B.C. and early decades of the first century A.D., until it was gradually replaced by blown-glass unguentaria See also Anderson-Stojanović 1987, 11.

57 Bilde - Poulsen 2008, 280.

58 Corinth XIII, 167; Khairy 1980, 85-86; AndersonStojanović 1987, 110 ff, Fig. 1f-g, 4-7.

59 Agora V, 15, F50; 11; Tarsus I, Lev. 159, No. 730.
Similar bulbous unguentaria occur in the contexts of the same period ${ }^{60}$. Cat. Nos. 37-41 and 42 can be dated to the middle of the $1^{\text {st }}$ century A. D (Figure 4, U37U42). The other three examples (Cat. Nos. 43-45) are later (Figure 4, U43U45). Hayes dates similar examples to a period from the mid- $1^{\text {st }}$ century A. D. to the first half of the $2^{\text {nd }}$ century A.D. ${ }^{61}$. Also similar unguentaria occur in the contexts of the same period in Corinth ${ }^{62}$ and Tarsus ${ }^{63}$.

Cat. Nos. 46 and 47 are the smallest and latest of all the unguentaria in Tralleis (Figure 4, U46-U47). Parallels for the smaller unguentaria are also problematic. These types of unguentaria were probably made in the late $1^{\text {st }}$ century A. D. These two examples mentioned above show the same typical short-necked bulbous shape as the classical glass type Isings ${ }^{64}$.

\section{Conclusion}

In order to summarize the findings concerning the materials examined in this article, it can be stated that only a section of the western necropolis of Tralleis, which covers a considerable wide area, was excavated during the 2007 excavation season. Out of more than 60 unguentaria recovered from these excavations dating back to the Hellenistic and Roman periods, only 47 are included in this article. In terms of a stratigraphical evaluation, the work site where the findings were uncovered during the 2007 season was not

60 Hayes 1976, 34, Pl. 19, Fig. 158.

61 Hayes 1975, Pl. 37, Nos. 341-343.

62 Bruneau 1970a, Fig. 117, 61.15.

63 Tarsus I, Pl. 159, Fig. 734.

64 Isings 1957, form 6/28a. This form was especially common during the $1^{\text {st }}$ century A.D and continued to be used in the $2^{\text {nd }}$ and $3^{\text {rd }}$ centuries A. D. 
very suitable. The few coins ("Charon's obol") uncovered from the tomb were too corroded to make an evaluation. In addition, the typological development of the finds indicate that the tomb was used in different periods for a considerable time commencing from the early Hellenistic period to the second half of the first century A.D. For this reason, the dating of the findings, arrived at by comparing, should be considered in terms of the form development or with the examples of the contexts the dates of which are precisely known.

During the work conducted in the western necropolis, tombs of different types and periods were revealed and as a result of the evaluations it was understood that the necropolis area was used from the $4^{\text {th }}$ century B.C. to $4^{\text {th }}$ century A.D. The unguentaria we have evaluated here were discovered from both cremation and inhumation graves. On the other hand, no unguentaria were encountered in tile graves which most of them date back to the $4^{\text {th }}$ century and where grave gifts are abundantly present.

A large majority of the unguentaria was found distributed among five Klinai within the chamber tomb. It should be noted that the distribution form among the findings, out of the 47 samples, 35 were of fusiform and 12 were of bulbous form. After some time, a large part of these samples were recovered, form developments between the late $4^{\text {th }}$ century B.C. and the late $1^{\text {st }}$ century A.D. were able to be completely followed.

As understood from the many unguentaria recovered from the necropolis area, Tralleis unguentaria, as is the case in many city centers, were most likely to have been placed to present grave gifts or offensive odors. Unguentaria, which makes up an original form of the Hellenistic and Roman periods ceramics, leads to important conclusions when examined in form development in Tralleis.

Accordingly, Tralleis unguentaria reflect the specific characteristic features of Anatolia. Excluding a few examples belonging to the early Hellenistic period, which are horizontally decorated with a colored band on the neck and body, all of them are non-decorated and bear no handle. The clay of the unguentaria was evaluated according to the Munsell catalogue and ranges of color from $2.5 \mathrm{YR}$ $7 / 4$, 5YR $6 / 6$ or $5 \mathrm{YR} 7 / 3-4$ tons were determined. In all of the examples, mica remains were found and most were observed to be of standard dimensions.

Although the earliest examples of the form development of Tralleis unguentaria indicate a date back to the early Hellenistic period, these examples only make up a very small number of the findings. Evaluations conducted on these types of examples between the latter half of $4^{\text {th }}$ century B.C. and the beginning of $3^{\text {rd }}$ century B.C. resembles the unguentaria body of lekythoi or amphoriskos forms. In these types of examples, the neck is short, the shoulders are wide, the body is round and the mount is flat and wide. In these forms some of the neck and body have a red or reddish brown colored band. Similar to these types of Tralleis examples can be found within the context of Corinthian and Athenian agoras towards the end of the $4^{\text {th }}$ century B.C. 
In evaluating all the examples recovered from Tralleis from a chronological perspective, a large majority of the findings is made up of unguentaria dating back to the $2^{\text {nd }}$ century B.C. In particular, examples dating back to the middle and the latter half of the $2^{\text {nd }}$ century B.C. are more abundant in numbers. Many of these examples have a spindle-shaped body, downturned rim, long tubular neck, cylindrical stem, and small distinct ring foot. Similar forms can be seen at Kerameikos, Athenian Agora, Corinth, Delos, Pergamon, Labraunda, Ephesos, Metropolis, Stratonikeia, Tarsus and Eretria.

As known, the $2^{\text {nd }}$ century B.C. is the most active period of Tralleis in terms of politics and history. During this period Tralleis, foremost with the city of Pergamon, undertook both commercial and political relations with many city centers in western Anatolia and played an active regional role. Again during this period, it is known that the city was productive in the area of sculpture. Thus, the $2^{\text {nd }}$ century B.C., in which unguentaria dating to this time were extensively recovered, was the most productive artistic age for Tralleis.

Being the point, the examples from Tralleis dating back to the $2^{\text {nd }}$ century B.C. can be chronologically evaluated according to different phases by examining form development. The increase in multiple productions during the abovementioned century resulted in the deterioration of labour and quality. This situation is also valid for Tralleis examples as well. In particular, after the mid $2^{\text {nd }}$ century B.C., the foot of the unguentaria be- came longer and towards the end of the century the length of the neck and foot became equal and the diameter of the foot decreased. Among the Tralleis unguentaria there are many examples of these types. Furthermore, in the development from the earlier to the later period, a form where the length increases from short to large, from a round globular body to a smaller body and from short foot to a longer foot can be observed.

The wide shoulder pattern seen in the early Hellenistic period disappeared by the Tralleis examples that reflect the form from the middle to the late $2^{\text {nd }}$ century B.C. Some of the bodies of the examples are asymmetric. With its unbalanced and disproportionate body, these types of unguentaria were difficult to stand up and difficult to store an item inside it. Therefore, these types of examples are non-functional in terms of form. These types of unguentaria dating towards the end of the Hellenistic period can be seen not only in Tralleis but also in many centers in Anatolia. In addition to the deterioration in form from the earlier until the later periods discussed above, the unguentaria made to place in graves were of lower quality compared to daily use or those made for exports.

The fusiform unguentaria with its thin foot form that made it difficult to stand was replaced by the bulbous formed unguentaria of the early Roman period. Twelve samples of this form were recovered at the Tralleis necropolis. In comparing the bulbous unguentaria from Tralleis with similar examples and considering the form development, these examples date back from the beginning to the end 
of $1^{\text {st }}$ century A.D. The bulbous samples were distributed among the klinai within the chamber tomb or found at different levels at various locations outside of the structural area. In examining these examples, the majority has a long neck, a rounded body and a flat base.

In all of the examples, the unbalanced, long foot observed in the late Hellenistic period examples can no longer be seen. With the long neck, a body that soundly stands level and with a foot in proportion to this, the bulbous examples are much more functional compared to the fusiform examples of the late Hellenistic period.

Since all of the unguentaria examples recovered from the western necropolis excavations in 2007, upon examination, were not of different clay, glaze and shapes, these examples can be considered as Tralleis production. However, it is not possible to identify the workshops from the unguentaria uncovered from the excavation that took place at the western necropolis area alone. Aside from this, there is no stamp or a mark on the unguentaria to identify the workshops. Despite this, among the unguentaria recovered, there are similar examples that appear to have come from the same craftsman. In particular, within the group of examples of the $2^{\text {nd }}$ century B.C. almost all have similar forms and technical features. Thus, these examples used extensively during the $2^{\text {nd }}$ century B.C. in Tralleis are considered as local production.

In conclusion, this article has attempted to evaluate the Tralleis unguentaria that were uncovered during the 2007 excavation season in a chronological or- der. As a result of the examinations undertaken, the form development of unguentaria in Tralleis, intensive during the $2^{\text {nd }}$ century B.C., was evaluated from late $4^{\text {th }}$ century B.C. until the end of $1^{\text {st }}$ century A.D. The materials obtained during this excavation work show similarities with the examples both in Anatolia and in other Greek provinces as well. Moreover, the unity within the materials supports the view that they were local products. Despite this, the city workshops, regional similarities and differences and identifying interactions will only be possible by evaluating the materials to be uncovered in the future excavations. 


\section{CATALOGUE $^{65}$}

\section{Cat. No.1; U1}

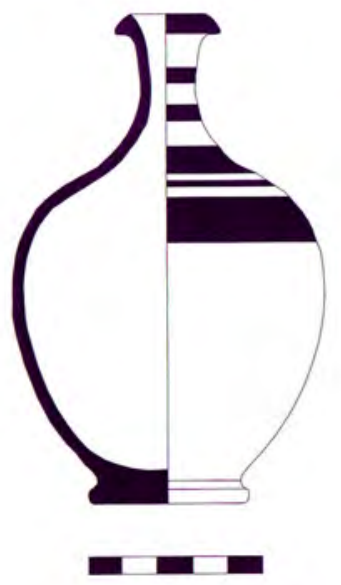

Excavation Inv. No: TRL07NASM153 Find Place: From sarcophagus 2.

H. 14,1 cm; D. Rim. 2 cm; D. Foot. 4, 3 $\mathrm{cm}$.

State of Conservation: Intact.

Munsell: 2.5YR 7/6 (light red).

Form and general description: Globular body, convex mouth, short neck, high shoulder, small feet; decorated with red band on neck and shoulder.

Parallels: Corinth VII, Pl. 58, Figs. 585586; Corinth XIII, Pl. 76, Figs. 10-11; Pl. 77, Fig. 16; Pl. 78, Fig. 7; Agora XXIX, Pl. 85, Fig. 72, 1163-1167.

Date: Third quarter of the $4^{\text {th }}$ century B.C. or a little later.

\footnotetext{
65 The measurements are given in centimeters (according to preserved maximum height and diameter) and fabric colors are described by reference to the Munsell Soil Color Charts (Year 2000 Revised Washable Edition), and the closest Munsell numbers are included in the catalog.
}

\author{
Cat. No.2; U2
}

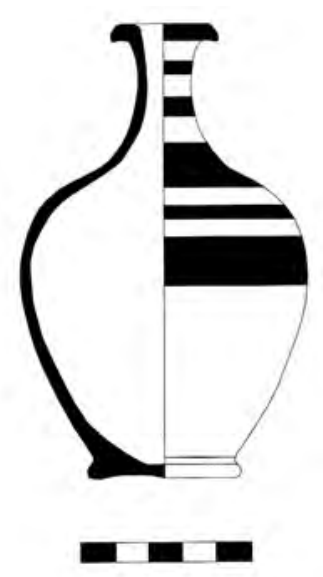

Excavation Inv. No: TRL07NASM159 Find Place: From sarcophagus 2.

H. 14, 3 cm; D. Rim. 3, 1 cm; D. Foot. 4, $4 \mathrm{~cm}$.

State of Conservation: Intact.

Munsell: 2.5YR 7/6 (light red).

Form and general description: Globular body; convex mouth; short neck; high shoulder; small feet; decorated with red band on neck and shoulder.

Parallels: Corinth VII, Pl. 58, Figs. 585586; Corinth XIII, Pl. 76, Figs. 10-11; Pl. 77, Fig. 16; Pl. 78, Fig. 7; Agora XXIX, Pl. 85, Figs. 72, 1163-1167.

Date: Third quarter of the $4^{\text {th }}$ century B.C. or a little later. 
Cat. No.3; U3

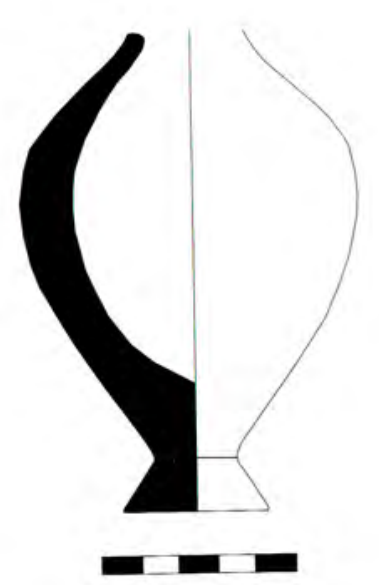

Excavation Inv. No: TRL07NA229

Find Place: From trench 1.

Max. P. H. 12, 5 cm; D. Foot. 3, 7 cm.

State of Conservation: Intact except for neck and rim.

Munsell: 2.5YR 7/4 (light reddish brown).

Form and general description: Globular body, high shoulder; conical ring base.

Parallels: Thompson 1934, Fig. 15, B7; Goldman 1940, Fig. 199, No. 16; Vessberg - Westholm 1956, Fig. 24. 1; Corinth VII, Pl. 58, Figs. 584-585; Corinth XIII, Pl. 76, Figs. 10-11; Pl. 77, Fig. 16; Pl. 78, Fig. 7; Boulter 1963, Pl. 46, H1; Labraunda II.1, Pl. 12, No. 163; Anderson-Stojanović 1987, Fig. 2, Shape 1; Ölmez 2000, Lev. XXIV, K.9.

Date: Early $3^{\text {rd }}$ century B.C.

\author{
Cat. No.4; U4
}

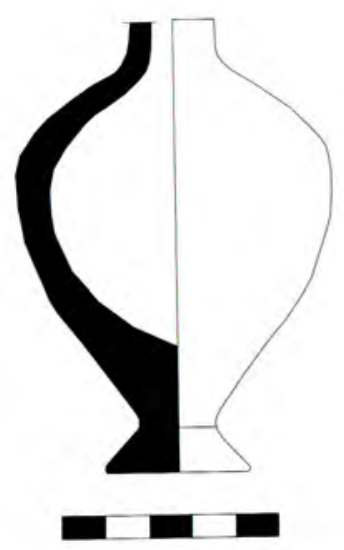

Excavation Inv. No: TRL07NA228

Find Place: From trench 1.

Max. P. H. 10, 4 cm; D. Foot. 3, 2 cm.

State of Conservation: Intact except for neck and rim.

Munsell: 2.5YR 7/6 (light red).

Form and general description: Globular body, high shoulder, conical ring base.

Parallels: Thompson 1934, Fig. 15, B7; Goldman 1940, Fig. 199, No. 16; Vessberg - Westholm 1956, Fig. 24. 1; Corinth VII, Pl. 58, Figs. 584-585; Corinth XIII, Pl. 76, Figs. 10-11; Pl. 77, Fig. 16; Pl. 78, Fig. 7; Boulter 1963, Pl. 46, H1; Labraunda II.1, Pl. 12, No. 163; Anderson-Stojanović 1987, Fig. 2, Shape 1; Ölmez 2000, Lev. XXIV, K.9.

Date: Early $3^{\text {rd }}$ century B.C. 


\author{
Cat. No.5; U5
}

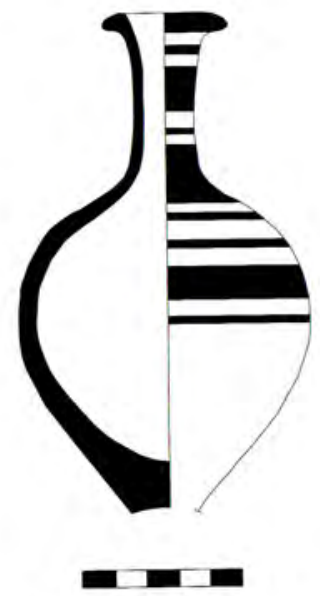

Excavation Inv. No: TRL07NADM27

Find Place: From kline 1 in the chamber tomb.

Max. P. H. 15, 6 cm; D. Rim. 4, 1 cm.

State of Conservation: Foot missing.

Munsell: 10R 6/4 (pale red).

Form and general description: Globular body, convex mouth, tall neck, high shoulder. Decorated with red band on neck and shoulder.

Parallels: Thompson 1934, Fig. 15, B7; Goldman 1940, Fig. 199, No. 16; Vessberg - Westholm 1956, Fig. 24. 1; Corinth VII, Pl. 58, Figs. 585-586; Corinth XIII, Pl. 76, Figs. 10-11; Pl. 77, Fig. 16; Pl. 78, Fig. 7; Boulter 1963, Pl. 46, H1; Labraunda II.1, Pl. 12, No. 163; Anderson-Stojanović 1987, Fig. 2, Shape 1; $A g$ ora XXIX, Fig. 72, Pl. 85, 1168-1169.

Date: Early $3^{\text {rd }}$ century B.C.

\author{
Cat. No.6; U6
}

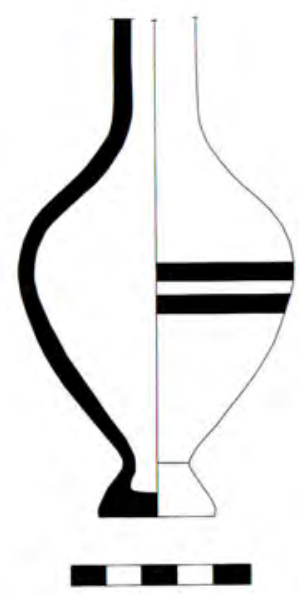

Excavation Inv. No: TRL07NA221

Find Place: From trench 1.

Max. P. H. 14, 2 cm; D. Foot. 3, 2 cm.

State of Conservation: Intact except for neck and rim.

Munsell: 2.5YR 7/6 (light red).

Form and general description: Globular body; tubular neck; high shoulder; conical base. Decorated with red band on body.

Parallels: Thompson 1934, Fig. 15, B7; Goldman 1940, Fig. 199, No. 16; Vessberg - Westholm 1956, Fig. 24. 1; Corinth VII, Pl. 58, Figs. 584-585; Corinth XIII, Pl. 76, Figs. 10-11; Pl. 77, Fig. 16; Pl. 78, Fig. 7; Boulter 1963, Pl. 46, H1; Labraunda II.1, Pl. 12, No. 163; Anderson-Stojanović 1987, Fig. 2, Shape 1.

Date: Early $3^{\text {rd }}$ century B.C. 
Cat. No.7;U7

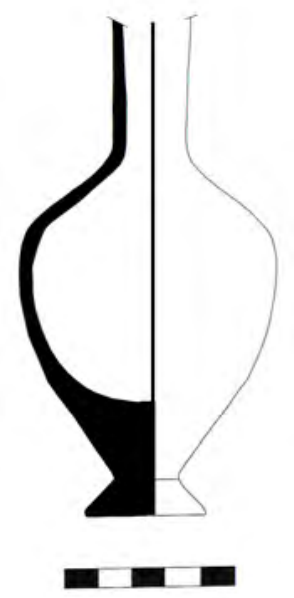

Excavation Inv. No: TRL07NADM64

Find Place: From niche in the chamber tomb.

Max. P. H. 14, 6 cm; D. Foot. 3, 9 cm.

State of Conservation: Intact except for neck and rim; traces of burning on exterior.

Munsell: 10R 6/4 (pale red).

Form and general description: Globular body; tubular neck; high shoulder; conical base.

Parallels: Thompson 1934, Fig. 15, B7; Goldman 1940, Fig. 199, No. 16; Vessberg - Westholm 1956, Fig. 24. 1; Corinth VII, Pl. 58, Figs. 584-585; Corinth XIII, Pl. 76, Figs. 10-11; Pl. 77, Fig. 16; Pl. 78, Fig. 7; Boulter 1963, Pl. 46, H1; Labraunda II.1, Pl. 12, No. 163; Anderson-Stojanović 1987, Fig. 2, Shape 1.

Date: Early $3^{\text {rd }}$ century B.C.

\section{Cat. No.8; U8}

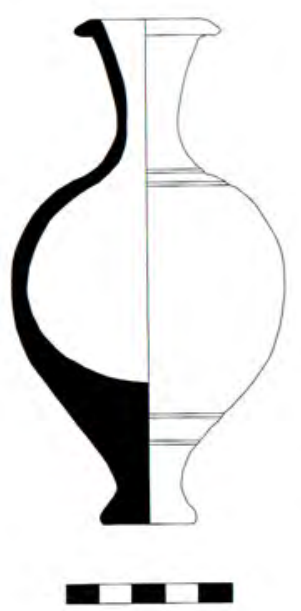

Excavation Inv. No: TRL07NADM21

Find Place: From kline 4 in the chamber tomb

H. 14, 8 cm; D. Rim. 3 cm; D. Foot. 2, 8 $\mathrm{cm}$.

State of Conservation: Intact.

Munsell: 10R 6/4 (pale red).

Form and general description: Fine micaceous, globular body, convex mouth, short neck, high shoulder, small feet.

Parallels: Thompson 1934, Fig. 15, B7; Vessberg - Westholm 1956, Fig. 24.1; Corinth XIII, Pl. 76, Figs. 10-11; Pl. 77, Fig. 16; Pl. 78, Fig. 7; Boulter 1963, Pl. 46, H1; Labraunda II.1, Pl. 12, No. 163; Anderson-Stojanović 1987, Fig. 2, Shape 1.

Date: Early $3^{\text {rd }}$ century B.C. 
Cat. No.9; U9

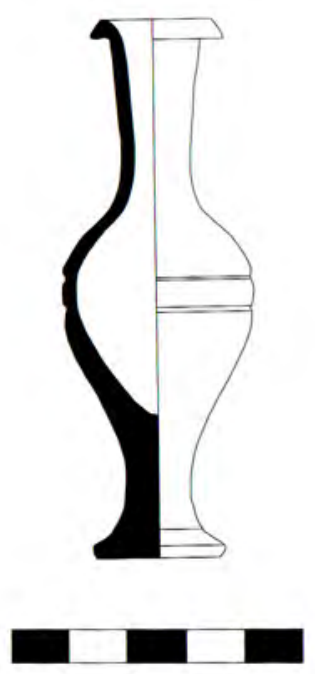

Excavation Inv. No: TRL07NADM31

Find Place: From kline 5 in the chamber tomb.

H. 9, 4 cm; D. Rim. 1, 9 cm; D. Foot. 2, 2 $\mathrm{cm}$.

State of Conservation: Intact.

Munsell: 10R 6/4 (pale red).

Form and general description: Spindleshaped body; downturned rim; long tubular neck; cylindrical stem, small distinct ring foot.

Parallels: Thompson 1934, Fig. 9, A 64, Fig. 15, B 6.

Date: First half of the $3^{\text {rd }}$ century B.C.
Cat. No.10; U10
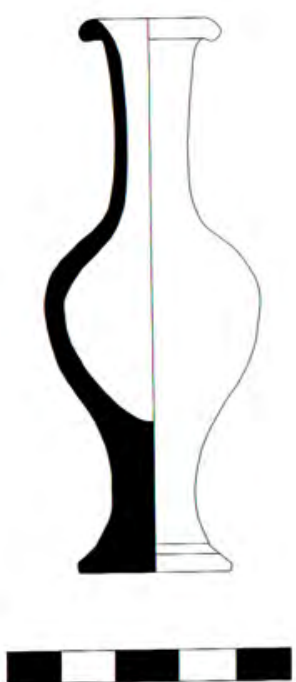

Excavation Inv. No: TRL07NADM23. Find Place: From kline 5 in the chamber tomb.

H: 9, 7 cm; D. Rim. 2, 5 cm; D. Foot. 2, 7 $\mathrm{cm}$.

State of Conservation: Intact.

Munsell: 2.5YR 6/6-8 (light red).

Form and general description: Spindleshaped body; downturned rim; long tubular neck; cylindrical stem; small distinct ring foot.

Parallels: Thompson 1934, Fig. 9, A 64, Fig. 15, B 6.

Date: First half of the $3^{\text {rd }}$ century B.C. 
Cat. No.11; U11

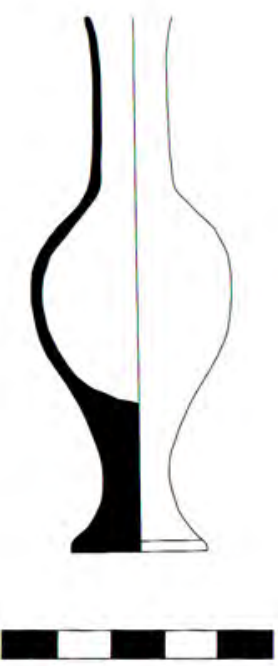

Excavation Inv. No: TRL 07NA224

Find Place: From trench 1.

H. 9, 8 cm; D. Rim. 1, 6 cm; D. Foot. 2, 5 $\mathrm{cm}$.

State of Conservation: Intact.

Munsell: 5YR 6/6 (reddish yellow).

Form and general description: Spindleshaped body; downturned rim; long tubular neck; cylindrical stem; small distinct ring foot.

Parallels: Thompson 1934, Fig. 52, C 76; Labraunda II.1, Pl. 12, No. 165; Agora XXIX, Fig. 72, Pl. 85, 1171.

Date: Second half of the $3^{\text {rd }}$ century B.C. or late $3^{\text {rd }}$ century B.C.
Cat. No.12; U12

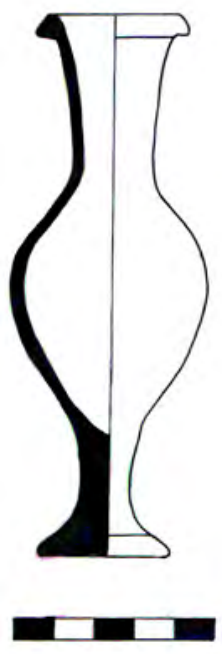

Excavation Inv. No: TRL07NADM16

Find Place: From trench 1.

H. 12, 8 cm; D. Rim. 2, 6 cm; D. Foot. 2, $3 \mathrm{~cm}$.

State of Conservation: Intact.

Munsell: 5YR 6/3-4 (light reddish brown). Form and general description: Spindle-shaped body; downturned rim; long tubular neck; cylindrical stem; small distinct ring foot.

Parallels: Thompson 1934, Fig. 52, C 76; Labraunda II.1, Pl. 12, No. 165; Agora XXIX, Fig. 72, Pl. 85, 1171.

Date: Second half of the $3^{\text {rd }}$ century B.C. or late $3^{\text {rd }}$ century B.C. 
Cat. No.13; U13

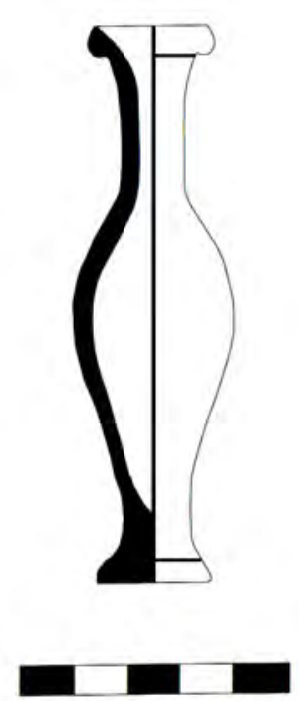

Excavation Inv. No: TRL 07 NA SM 162 Find Place: From sarcophagus 3.

H. 10, 5 cm; D. Rim. 2, 2 cm; D. Foot. 2, $3 \mathrm{~cm}$.

State of Conservation: Intact.

Munsell: 5YR 7/4 (pink).

Form and general description: Slendershaped body; downturned rim; long tubular neck; cylindrical stem; small distinct ring foot.

Parallels: Bruneau 1970a, 448; FiE IX 2/2, Taf. 210, 011, Taf. 213, 020.

Date: Early $2^{\text {nd }}$ century B.C.
Cat. No.14; U14

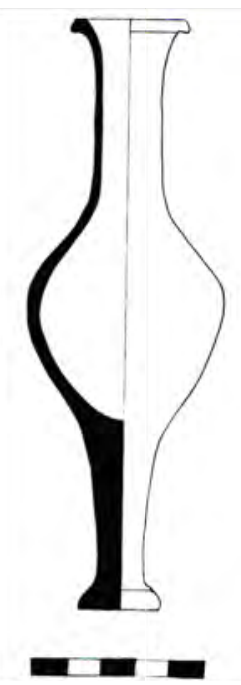

Excavation Inv. No: TRL07NADM98

Find Place: From kline 4 in the chamber tomb.

H. 16, 2 cm; D. Rim. 2, 9 cm; D. Foot. 2 $\mathrm{cm}$.

State of Conservation: Intact.

Munsell: 10R 7/4 (pale red).

Form and general description: Spindleshaped body; downturned rim; long tubular neck; cylindrical stem; small distinct ring foot.

Parallels: Thompson 1934, Fig. 52, C 76; Labraunda II.1, Pl. 12, No. 165; Agora XXIX, Fig. 72, Pl. 85, 1171.

Date: Early $2^{\text {nd }}$ century B.C. 
Cat. No.15; U15

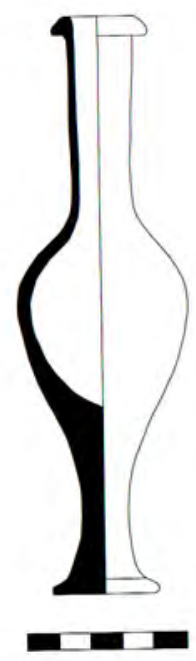

Excavation Inv. No: TRL07NADM06

Find Place: From kline 4 in the chamber tomb.

H. 18, 4 cm; D. Rim. 2, 2 cm; D. Foot. 3, $2 \mathrm{~cm}$.

State of Conservation: Intact.

Munsell: 2.5YR 7/3-4 (light reddish brown).

Form and general description: Spindleshaped body; downturned rim; long tubular neck; cylindrical stem; small distinct ring foot.

Parallels: Edwards 1959, 267-268, Pl. 68, Fig. 21; Labraunda II.1, Pl. 12, No. 165. Date: First half of the $2^{\text {nd }}$ century B.C.
Cat. No.16; U16
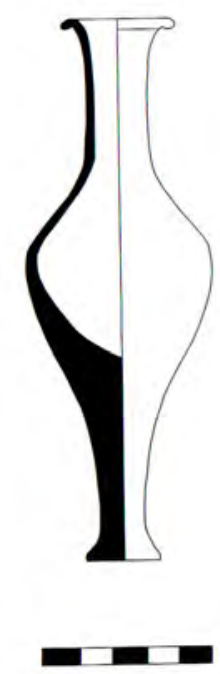

Excavation Inv. No: TRL07NADM07

Find Place: From kline 1 in the chamber tomb.

H. 15, 9 cm; D. Rim. 2, 7 cm; D. Foot. 2, $1 \mathrm{~cm}$.

State of Conservation: Intact.

Munsell: 2.5YR 6/3-4 (light reddish brown).

Form and general description: Spindleshaped body; downturned rim; long tubular neck; cylindrical stem; small distinct ring foot.

Parallels: Kerameikos IX, Taf. 69, No. 390; Agora XXIX, Pl. 85, No. 1170.

Date: Mid- $2^{\text {nd }}$ century B.C. 
Cat. No.17; U17

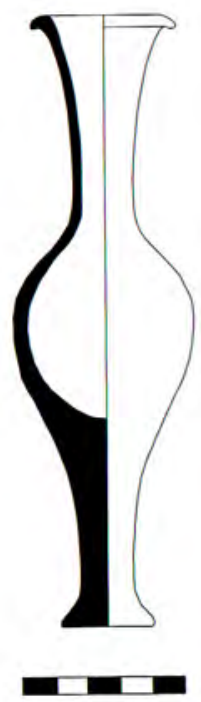

Excavation Inv. No: TRL07NADM99

Find Place: From keline 4 in the chamber tomb.

H. 19, 4 cm; D. Rim. 3, 9 cm; D. Foot. 2, $8 \mathrm{~cm}$.

State of Conservation: Intact.

Munsell: 10R 6/3-4 (pale red).

Form and general description: Spindleshaped body; downturned rim; long tubular neck; cylindrical stem; small distinct ring foot.

Parallels: Kerameikos IX, Taf. 69, No. 390; Agora XXIX, Pl. 85, No. 1170; Civelek 2001, Lev. XXX, U46.

Date: Mid- $2^{\text {nd }}$ century B.C.
Cat. No.18; U18

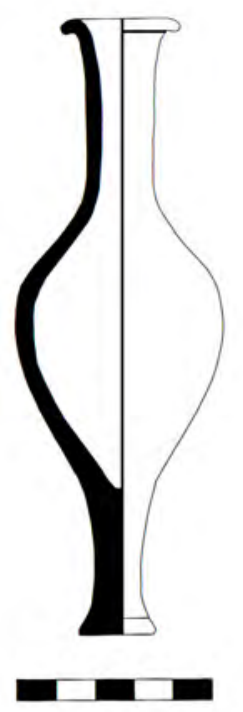

Excavation Inv. No: TRL07NADM22

Find Place: From kline 1 in the chamber tomb.

H. 15, 8 cm; D. Rim. 3 cm; D. Foot. 1, 8 $\mathrm{cm}$.

State of Conservation: Intact.

Munsell: 5YR 6/4 (light reddish brown). Form and general description: Spindleshaped body; downturned rim; long tubular neck; cylindrical stem; small distinct ring foot.

Parallels: Kerameikos IX, Taf. 69, No. 390; Gürler 1994, Çiz. 39, 137-141; Agora XXIX, Pl. 85, No. 1170.

Date: Mid- $2^{\text {nd }}$ century B.C. 
Cat. No.19; U19

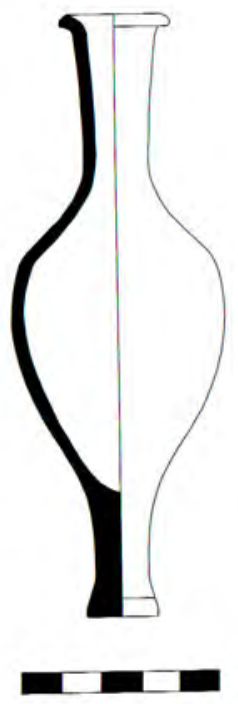

Excavation Inv. No: TRL07NADM 09 Find Place: From kline 1 in the chamber tomb.

H. 15, 5 cm; D. Rim. 2, 4 cm; D. Foot. 1, $8 \mathrm{~cm}$.

State of Conservation: Intact.

Munsell: 5YR 6/4 (light reddish brown). Form and general description: Spindleshaped body; downturned rim; long tubular neck; cylindrical stem; small distinct ring foot.

Parallels: Kerameikos IX, Taf. 69, No. 390; Gürler 1994, Çiz. 39, 137-141; Agora XXIX, Pl. 85, No. 1170. Civelek 2001, Lev. XXX, U29.

Date: Mid- $2^{\text {nd }}$ century B.C.
Cat. No.20; U20

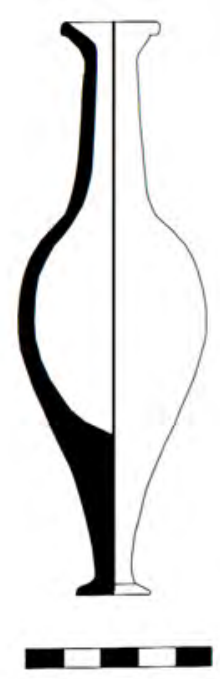

Excavation Inv. No: TRL07NADM18

Find Place: From kline 3 in the chamber tomb.

H. 15, 4 cm; D. Rim. 2, 5 cm; D. Foot. 1, $9 \mathrm{~cm}$.

State of Conservation: Intact.

Munsell: 5YR $7 / 4$ (pink).

Form and general description: Spindleshaped body; downturned rim; long tubular neck; cylindrical stem; small distinct ring foot.

Parallels: Kerameikos IX, Taf. 69, No. 390; Agora XXIX, Pl. 85, No. 1170.

Date: Mid- $2^{\text {nd }}$ century B.C. 


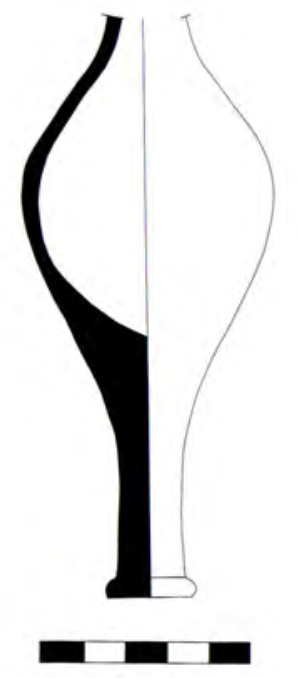

Excavation Inv. No: TRL07NADM34

Find Place: From kline 2 in the chamber tomb.

Max. P. H. 13, 7 cm; D. Rim. 1, 7 cm; D. Foot. 2, $1 \mathrm{~cm}$.

State of Conservation: The upper part of the neck and rim are missing.

Munsell: 10R 7/4 (pale red).

Form and general description: Spindleshaped body; downturned rim; long tubular neck; cylindrical stem; small distinct ring foot.

Parallels: Tarsus I, Fig. 135, No. 234; Bruneau 1970b, 507; Kerameikos IX, Taf. 69, No. 390; Agora XXIX, Pl. 85, No. 1170.

Date: Mid- $2^{\text {nd }}$ century B.C.

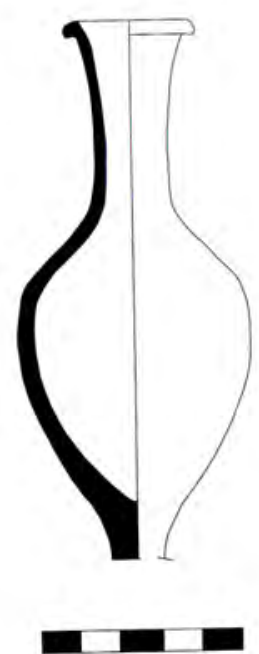

Excavation Inv. No: TRL07NADM28

Find Place: From kline 1 in the chamber tomb.

Max. P. H. 13, 4 cm; D. Rim.3 cm.

State of Conservation: Foot missing. Munsell: 10R 6/3 (pale red).

Form and general description: Spindleshaped body; downturned rim; long tubular neck; cylindrical stem; small distinct ring foot.

Parallels: Kerameikos IX, Taf. 69, No. 390; Agora XXIX, Pl. 85, No. 1170.

Date: Mid- $2^{\text {nd }}$ century B.C. 
Cat. No.23; U23

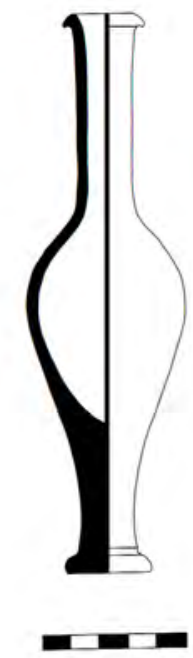

Excavation Inv. No: TRL07NADM05

Find Place: From kline 5 in the chamber tomb.

H. 19, 9 cm; D. Rim. 2, 9 cm; D. Foot. 2, $8 \mathrm{~cm}$.

State of Conservation: Intact.

Munsell: 2.5YR 7/6-8 (light red).

Form and general description: Fine micaceous fabric; body surface wellsmoothed; spindle-shaped body; downturned rim; long tubular neck; cylindrical stem; small distinct ring foot.

Parallels: Thompson 1934, Fig. 78, D 78;

Tarsus I, Fig. 135, No. 244; Metzger 1969, Taf. 28, No. 2.

Date: Second half of the $2^{\text {nd }}$ century B.C.
Cat. No.24; U24

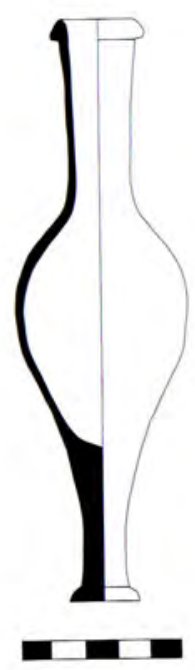

Excavation Inv. No: TRL07NADM12

Find Place: From kline 5 in the chamber tomb.

H. 17, 9 cm; D. Rim. 2, 9 cm; D. Foot. 2, $2 \mathrm{~cm}$.

State of Conservation: Intact.

Munsell: 5YR 6/3-4 (light reddish brown). Form and general description: Spindle-shaped body; downturned rim; Long tubular neck; cylindrical stem; small distinct ring foot.

Parallels: Thompson 1934, Fig. 78, D 78; Tarsus I, Fig. 135, No. 244; Metzger 1969, Taf. 28, No. 2; Samothrace 11, p. 219, S138-11; Ölmez 2000, Lev. XXXVI, K.33.

Date: Second half of the $2^{\text {nd }}$ century B.C. 
Cat. No.25; U25

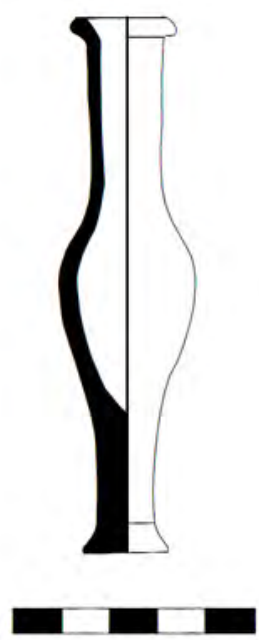

Excavation Inv. No: TRL07NADM56

Find Place: From kline 5 in the chamber tomb.

H. $11 \mathrm{~cm}$; D. Rim. 2, $1 \mathrm{~cm}$; D. Foot. 1, 8 $\mathrm{cm}$.

State of Conservation: Intact.

Munsell: 10R 7/3 (pale red).

Form and general description: Slendershaped body; downturned rim; long tubular neck; cylindrical stem; small distinct ring foot.

Parallels: Thompson 1934, Fig. 78, D 78; Tarsus I, Fig. 135, No. 244; Metzger 1969, Taf. 28, No. 2; Samothrace 11, p. 219, S138-11; Ölmez 2000, Lev. XXXIX, K 39.

Date: Second half of the $2^{\text {nd }}$ century B.C.
Cat. No.26; U26

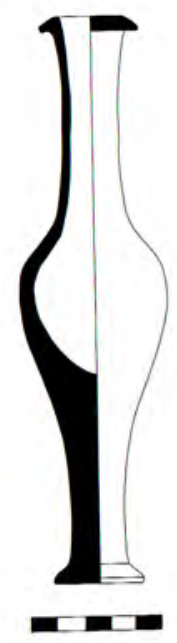

Excavation Inv. No: TRL07NADM14

Find Place: From kline 4 in the chamber tomb.

H. 21, 9 cm; D. Rim. 2, 4 cm; D. Foot. 3, $3 \mathrm{~cm}$.

State of Conservation: Intact.

Munsell: 5YR 6/3-4 (light reddish brown). Form and general description: Decorated with red band on neck and shoulder $^{66}$. Body surface well smoothed. Slender-shaped body; downturned rim; long tubular neck; cylindrical stem; small distinct ring foot.

Parallels: Thompson 1934, Fig. 78, D 78; Tarsus I, Fig. 135, No. 244; Metzger 1969 , Taf. 28, No. 2; Ölmez 2000, Lev. XXXV, K 30 .

Date: Second half of the $2^{\text {nd }}$ century B.C.

Boulter 1963, 125; Pemberton 1985, 285; Hausmann 1996, 32, fn. 130. 
Cat. No.27; U27

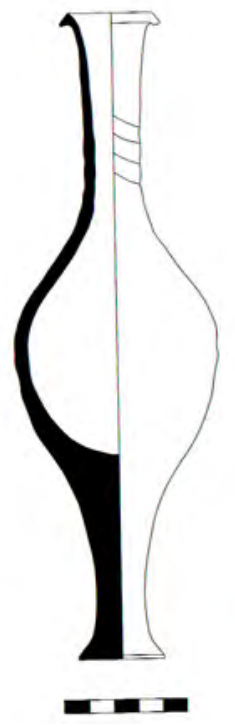

Excavation Inv. No: TRL07NADM15

Find Place: From kline 1 in the chamber tomb.

H. 26, 7 cm; D. Rim. 3, 4 cm; D. Foot. 3, $6 \mathrm{~cm}$.

State of Conservation: Intact.

Munsell: 5YR 6/3-4 (light reddish brown). Form and general description: Spindle-shaped body; downturned rim; long tubular neck; cylindrical stem; small distinct ring foot.

Parallels: Thompson 1934, Fig. 104, E 138; Bucovala 1967, 70, 71, 84.

Date: Late $2^{\text {nd }}$ century B.C.
Cat. No.28; U28

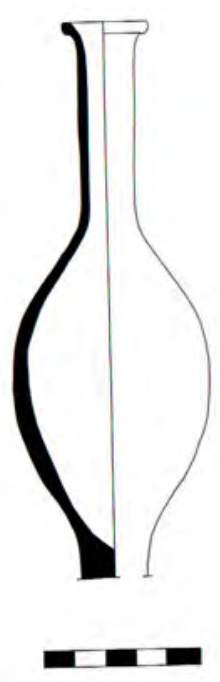

Excavation Inv. No: TRL07NADM17

Find Place: From kline 1 in the chamber tomb.

Max. P. H. 16, 9 cm; D. Rim. 2, 7 cm.

State of Conservation: Foot missing.

Munsell: 5YR 7/2 (pinkish gray).

Form and general description: Spindleshaped body; body surface well smoothed; downturned rim; long tubular neck; cylindrical stem.

Parallels: Thompson 1934, Fig. 104, E 138; Bucovala 1967, 70, 71, 84; Samothrace 11, S138-6; Okunak 2005, Çizim 14, Kat. No. 10.

Date: Late $2^{\text {nd }}$ century B.C. 
Cat. No.29; U29

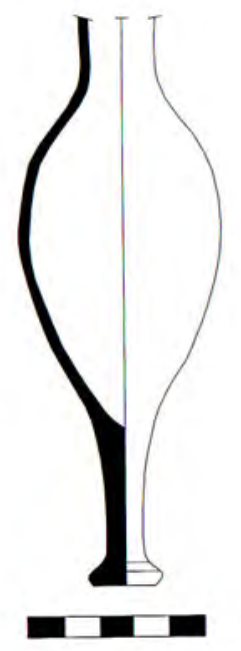

Excavation Inv. No: TRL07NADM77

Find Place: From kline 1 in the chamber tomb.

Max. P. H. 15, 6 cm; D. Foot. 1, 8 cm.

State of Conservation: Intact except for neck and rim.

Munsell: 10R 6/6 (light red).

Form and general description: Spindleshaped body; downturned rim; long tubular neck; cylindrical stem; small distinct ring foot.

Parallels: Thompson 1934, Fig. 104, E 138, Bucovala 1967, 70, 71, 84; Samothrace 11, S138-6.

Date: Late $2^{\text {nd }}$ century B.C.
Cat. No.30, U30

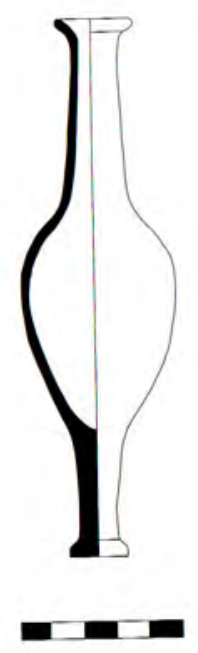

Excavation Inv. No: TRL07NADM08

Find Place: From kline 3 in the chamber tomb.

H. 16, 4 cm; D. Rim. 2, 4 cm; D. Foot. 1, $8 \mathrm{~cm}$.

State of Conservation: Intact.

Munsell: 5YR 7/3-4 (pink).

Form and general description: Spindleshaped body; downturned rim; long tubular neck; cylindrical stem; small distinct ring foot.

Parallels: Thompson 1934, Fig. 104, E 138, Bucovala 1967, 70, 71, 84; Samothrace 11, S138-11; Dündar 2006, Lev. XIX, U115.

Date: Late $2^{\text {nd }}$ century B.C. 
Cat. No.31; U31

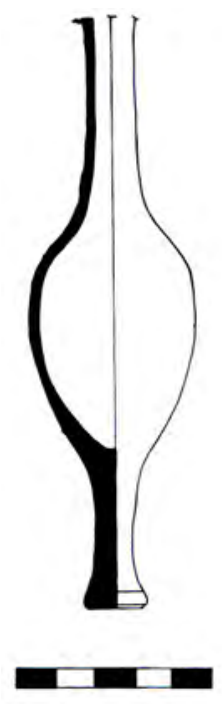

Excavation Inv. No: TRL07NADM24

Find Place: From kline 4 in the chamber tomb.

Max. P. H. 15, 5 cm; D. Foot. 1, 8 cm.

State of Conservation: Rim missing.

Munsell: 2.5YR 7/6-8 (light red).

Form and general description: Spindleshaped body; long tubular neck; cylindrical stem; small distinct ring foot.

Parallels: Thompson 1934, Fig. 104, E 138, Bucovala 1967, 70, 71, 84; Samothrace 11, S138-6.

Date: Late $2^{\text {nd }}$ century B.C.
Cat. No.32; U32

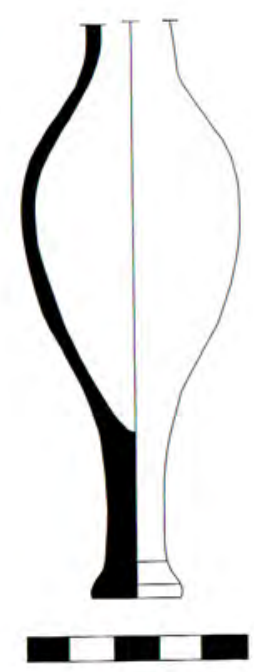

Excavation Inv. No: TRL07NA168

Find Place: From trench 1.

H. 13, $2 \mathrm{~cm}$; D. Foot. 1, $9 \mathrm{~cm}$.

State of Conservation: Intact except for neck and rim.

Munsell: 2.5YR 7/6 (light red).

Form and general description: Spindleshaped body; cylindrical stem; small distinct ring foot.

Parallels: Thompson 1934, Fig. 104, E 138; Bucovala 1967, 70, 71, 84; Samothrace 11, S138-9.

Date: Late $2^{\text {nd }}$ century B.C. 
Cat. No.33; U33

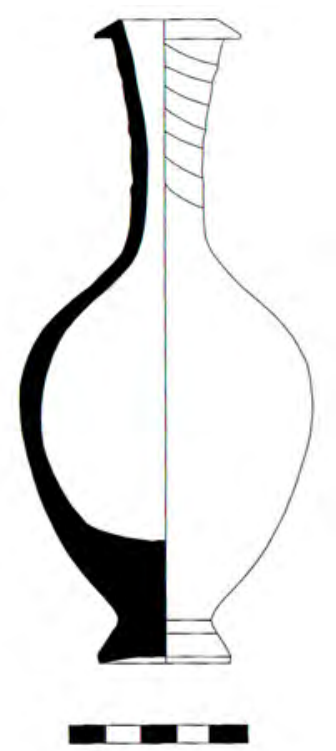

Excavation Inv. No: TRL07NADM02

Find Place: From kline 1 in the chamber tomb.

H. 18,8 cm; D. Rim. 2, 8 cm; D. Foot. 3, $8 \mathrm{~cm}$.

State of Conservation: Intact.

Munsell: 2.5YR 6/6-8 (light red).

Form and general description: Globular body; cylindrical stem; flaring pedestal foot; underside of base is concave. Parallels: Tarsus I, Fig. 135, No. 236; Agora V, Pl. 2, F 49; Wiseman - Mano-Zissi 1976 , 280, Fig. 11.

Date: Early $1^{\text {st }}$ century B.C.

\author{
Cat. No.34; U34
}

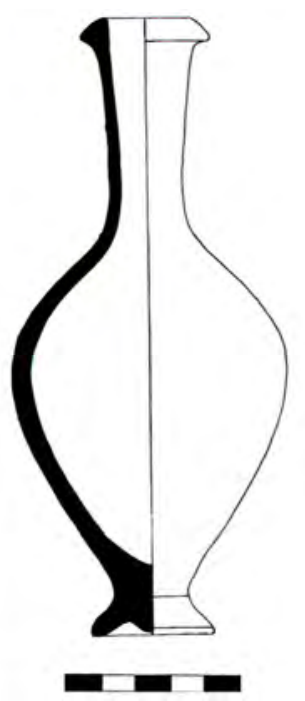

Excavation Inv.No: TRL07NADM01

Find Place: From kline 1 in the chamber tomb.

H. 19 cm; D. Rim. 4, 2 cm; D. Foot. 3, 8 $\mathrm{cm}$.

State of Conservation: Intact.

Munsell: 10R 6/4 (pale red).

Form and general description: Globular body; cylindrical stem; flaring pedestal foot; slightly concave base. Fine micaceous fabric; body surface well-smoothed.

Parallels: Agora V, Pl. 2, F 49; Wiseman Mano-Zissi 1976, 280, Fig. 11.

Date: Early $1^{\text {st }}$ century B.C. 
Cat. No.35; U35

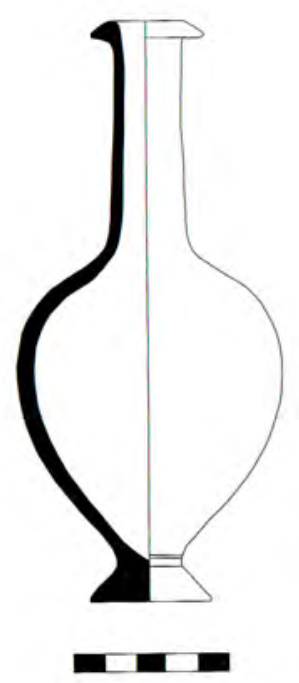

Excavation Inv. No: TRL07NADM30

Find Place: From kline 1 in the chamber tomb.

H. 18, 6 cm; D. Rim. 2, 2 cm; D. Foot. 3, $9 \mathrm{~cm}$.

State of Conservation: Intact.

Munsell: 10R 6/3 (pale red).

Form and general description: Globular body; cylindrical stem; flaring pedestal foot; underside of base is concave. Parallels: Agora V, Pl. 2, F 49; Wiseman Mano-Zissi 1976, 280, Fig. 11.

Date: Early $1^{\text {st }}$ century B.C.
Cat. No.36, U36

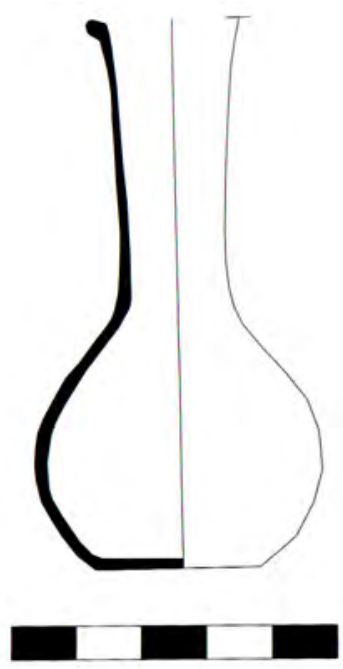

Excavation Inv. No: TRL07NA227.

Find Place: From trench 1.

H. 8, 4 cm; D. Foot. 2, $5 \mathrm{~cm}$.

State of Conservation: Neck broken, rim lost.

Munsell: 10R 6/4 (pale red).

Form and general description: Low bulging bulbous body; tall cylindrical neck; slightly concave base.

Parallels: Hayes 1976, 34, Pl. 19, Fig. 158.

Date: Early $1^{\text {st }}$ century A. D. 
Cat. No.37; U37

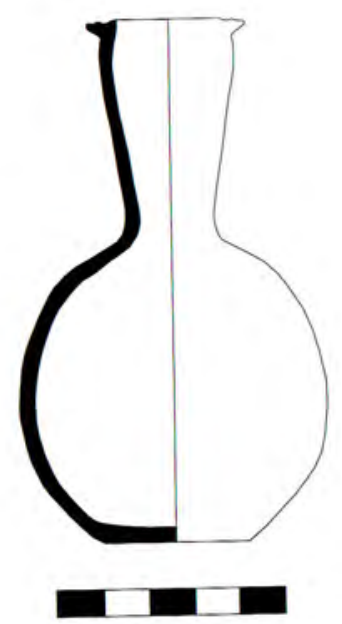

Excavation Inv. No: TRL07NADM29

Find Place: From kline 2 in the chamber tomb.

H. 11, 5 cm; D. Rim. 3, 6 cm; D. Foot. 3 $\mathrm{cm}$.

State of Conservation: Intact.

Munsell: 10R 6/3 (pale red).

Form and general description: Fairly bulbous body of truncated ovoid shape; tall tubular neck; everted rim; flat base.

Parallels: Tarsus I, Pl. 159, Fig. 730; Bruneau 1970a, Fig. 117, 61.15.

Date: Mid- $1^{\text {st }}$ century A. D.
Cat. No.38; U38

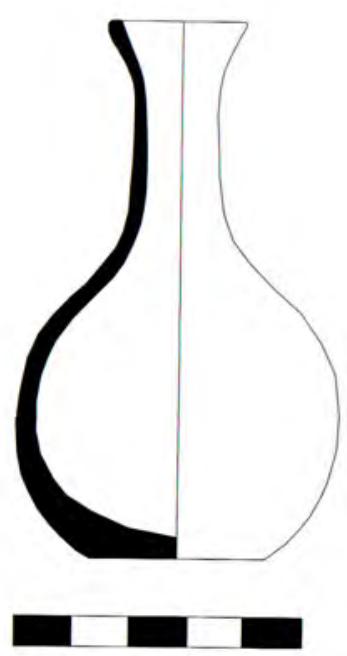

Excavation Inv. No: TRL07NADM20

Find Place: From kline 3 in the chamber tomb.

H. 9, $3 \mathrm{~cm}$; D. Rim. 2, 4 cm; D. Foot. 3 $\mathrm{cm}$.

State of Conservation: Intact.

Munsell: 10R 6/3 (pale red).

Form and general description: Bulbous body; narrow neck; everted rim; flat base. Parallels: Tarsus I, Pl. 159, Figs. 730, 732, 734-736; Bruneau 1970a, Fig. 117, 61.15. Date: Mid- $1^{\text {st }}$ century A. D. 
Cat. No.39; U39

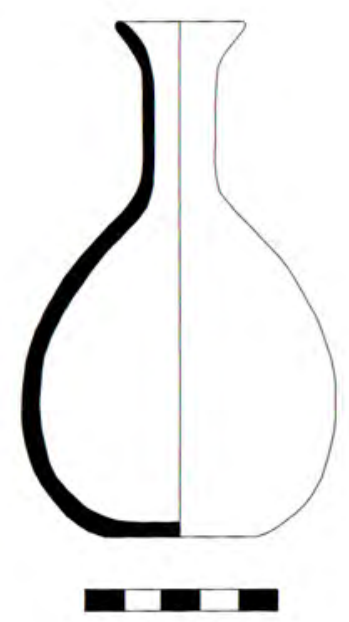

Excavation Inv. No: TRL07NADM13

Find Place: From kline 1 in the chamber tomb.

H. 13, 5 cm; D. Rim. 3, 3 cm; D. Foot. 3, $8 \mathrm{~cm}$.

State of Conservation: Intact.

Munsell: 10R 6/4 (pale red).

Form and general description: Bulbous body; short narrow cylindrical neck; everted rim; flat base.

Parallels: Tarsus I, Pl. 159, Figs. 730, 732, 734-736; Agora V, Pl. 2, F 50; Pl. 5, G 98; Lapp 1961, Type 92, D; Bruneau 1970 a, Fig. 117, 61.15; Anderson-Stojanović 1987, Fig. 1h; Civelek 2001, Lev. XXXIII, U51; FiE IX/3, Pl. 41, K 500.

Date: Mid- $1^{\text {st }}$ century A. D.
Cat. No.40; U40

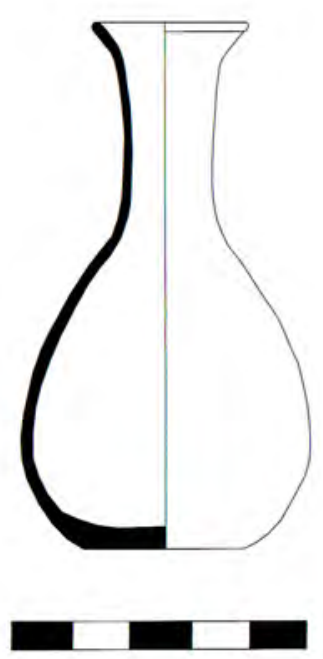

Excavation Inv. No: TRL07NADM26

Find Place: From kline 4 in the chamber tomb.

H. 8, 9 cm; D. Rim. 2, 6 cm; D. Foot. 3, 1 $\mathrm{cm}$.

State of Conservation: Intact.

Munsell: 10R 6/4 (pale red).

Form and general description: Ovoid sagging body; straight tubular neck; short flaring lip; small flat base.

Parallels: Tarsus I, Pl. 159, Fig. 735; Agora V, Pl. 2, F 50, Pl. 5, G 97-98; Pl. 18, M67; Bruneau 1970 a, Fig. 117, 61.15; Samothrace 11, S143-9; Civelek 2001, Lev. XXXIV, U1; Okunak 2005, Çizim 21, Kat. No. 17.

Date: Mid- ${ }^{\text {st }}$ century A. D. 
Cat. No.41; U41

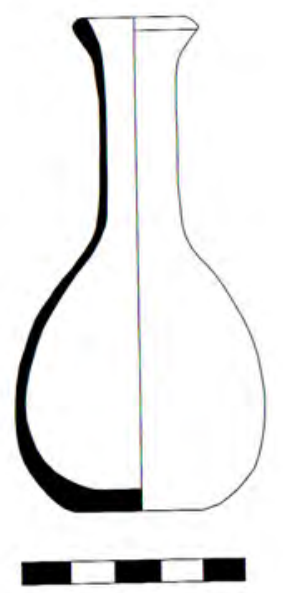

Excavation Inv. No: TRL07NADM11

Find Place: From kline 4 in the chamber tomb.

H. 11, 2 cm; D. Rim. 2, 9 cm; D. Foot. 2, $5 \mathrm{~cm}$.

State of Conservation: Intact.

Munsell: 10R 6/4 (pale red).

Form and general description: Sagging round-bodied form; tubular neck; flaring lip; small flat base.

Parallels: Tarsus I, Pl. 159, Fig. 734; Agora V, Pl. 2, F 50, Pl. 5, G 97-98; Pl. 18, M 67; Lapp 1961, 199 A, C-D; Bruneau 1970 a, Fig. 117, 61.15; Anderson-Stojanović 1987, 112, Fig. 7; Samothrace 11, S143-1; FiE IX/3, Pl. 41, L. 486; Dündar 2006, Lev. XXIII, U136; Okunak 2005, Çizim 21, Kat. No.17.

Date: Mid- $1^{\text {st }}$ century A. D.

\author{
Cat. No.42; U42
}

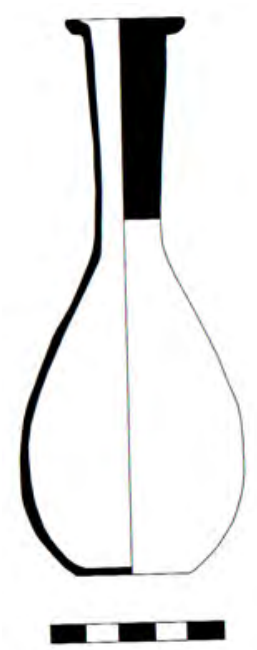

Excavation Inv. No: TRL07NADM03

Find Place: From kline 3 in the chamber tomb.

H. 16, 2 cm; D. Rim. 3, 4 cm; D. Foot. 3, $2 \mathrm{~cm}$.

State of Conservation: Intact.

Munsell: 10R 7/4 (pale red).

Form and general description: Low bulbous body; narrow cylindrical neck; short tapering flat-topped rim; sharply articulated. The shape is also found in glass (Isings 1957, form 26).

Parallels: Tarsus I, Pl. 159, Figs. 734-735; Agora V, Pl. 2, F 50, Pl. 5, G 97-98; Pl. 18, M 6-7; Bruneau 1970 a, Fig. 117, 61.15; Anderson-Stojanović 1987, 112, Fig. 7; Samothrace 11, S 143-1; FiE IX/3, Pl. 41, K 486.

Date: Mid-1 ${ }^{\text {st }}$ century A. D. 
Cat. No.43; U43

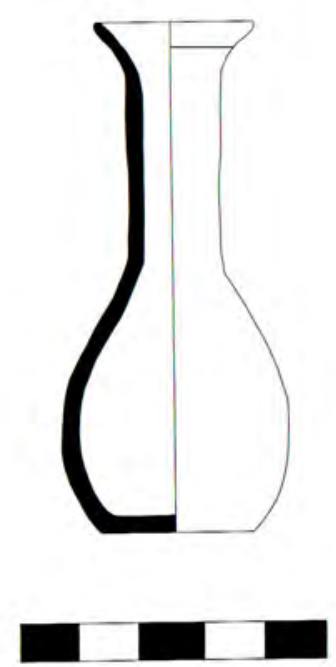

Excavation Inv. No: TRL07NADM10

Find Place: From kline 3 in the chamber tomb.

H. 8, 2 cm; D. Rim. 2, 5 cm; D. Foot. 2, 4 $\mathrm{cm}$.

State of Conservation: Intact.

Munsell: 10R 6/6 (light red).

Form and general description: Small ovoid body; tubular tall neck; thickened flaring lip; flat roughly-cut base.

Parallels: Tarsus I, Pl. 159, Fig. 734; Hayes 1976, Pl. 37, Fig. 340; Civelek 2001, Lev. XXXIV, U74; Dündar 2006, Lev. XXIV, U138.

Date: Second half of the $1^{\text {st }}$ century A. D.
Cat. No.44; U44

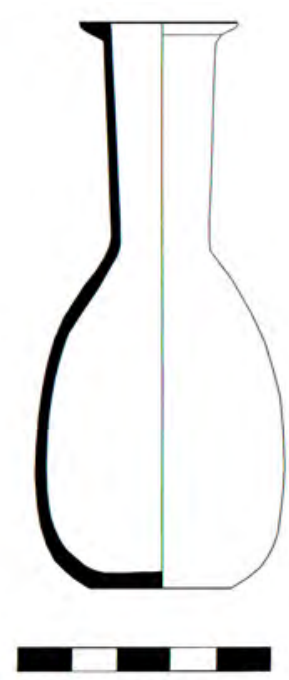

Excavation Inv. No: TRL07NADM25

Find Place: From kline 4 in the chamber tomb.

H. 11, 2 cm; D. Rim. 3 cm; D. Foot. 2, 6 $\mathrm{cm}$.

State of Conservation: Intact.

Munsell: 10R 6/6-8 (light red).

Form and general description: Ovoid body; tubular neck; small flat turned base. Parallels: Tarsus I, Pl. 159, Fig. 734; Bruneau 1970a, Fig. 117, 61.15; Dündar 2006, Lev. XXIII, Kat. No. U137.

Date: Second half of the $1^{\text {st }}$ century A. D. 
Cat. No.45; U45

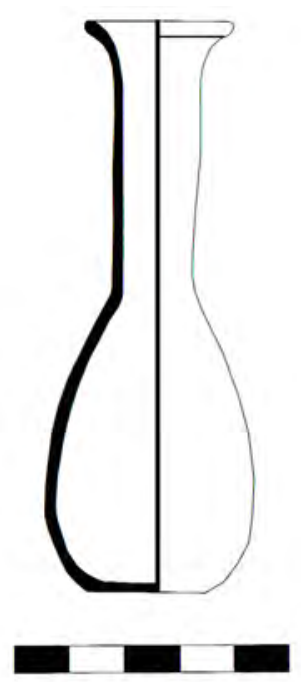

Excavation Inv. No: TRL07NADM19

Find Place: From kline 1 in the chamber tomb.

H. 10, 4 cm; D. Rim. 2, 8 cm; D. Foot. 2 $\mathrm{cm}$.

State of Conservation: Intact.

Munsell: 10R 6/4 (pale red).

Form and general description: Slender ovoid body; tall tubular neck; small flat base.

Parallels: Tarsus I, Pl. 159, Fig. 734; Bruneau 1970a, Fig. 117, 61.15.

Date: Second half of the $1^{\text {st }}$ century A. D.
Cat. No.46; U46
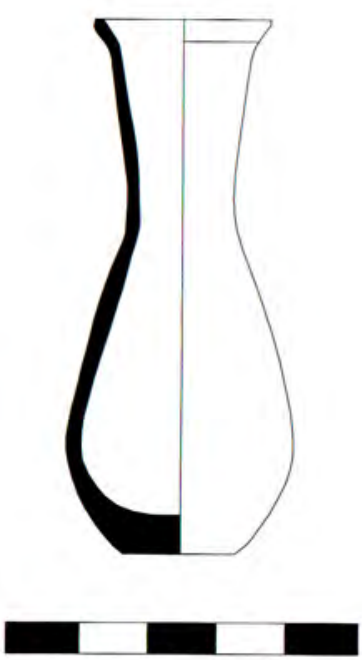

Excavation Inv. No: TRL07NA219

Find Place: From trench 1.

H. 7, 6 cm; D. Rim; 2, 5 cm; D. Foot. 1, 6 $\mathrm{cm}$.

State of Conservation: Intact.

Munsell: 2.5YR 6/6 (light red).

Form and general description: Same ware as Cat. No. 43; small ovoid body, short tubular neck, small flat base.

Parallels: Agora V, Pl. 5, G 97.

Date: Late $1^{\text {st }}$ century A. D. 
Cat. No.47; U47
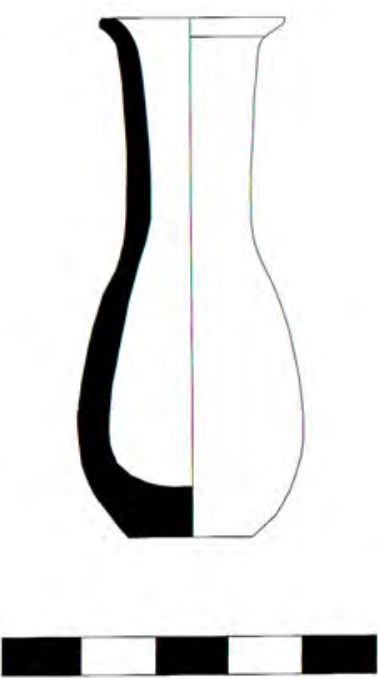

Excavation Inv. No: TRL07NA220

Find Place: From trench 1

H. 6, $9 \mathrm{~cm}$; D. Rim. 2, $5 \mathrm{~cm}$; D. Foot. 1, $6 \mathrm{~cm}$.

State of Conservation: Intact.

Munsell: 2.5YR 7/6 (light red)

Form and general description: Small ovoid body; short tubular neck; small flat base.

Parallels: Agora V, Pl. 5, G 97.

Date: Late $1^{\text {st }}$ century A. D.

\section{List of Figures:}

Graphic 1. Shape distribution of unguentaria in Tralleis.

Graphic 2. Color distribution of unguentaria in Tralleis.

Graphic 3. Chronological distribution of unguentaria in Tralleis.

Figure 1. Tralleis unguentaria from western necropolis, Cat. Nos. U1-U12.

Figure 2. Tralleis unguentaria from western necropolis, Cat. Nos. U13$\mathrm{U} 24$.

Figure 3. Tralleis unguentaria from western necropolis, Cat. Nos. U25U36.

Figure 4. Tralleis unguentaria from western necropolis, Cat. Nos. U37U47. 


\section{BIBLIOGRAPHY}

Agora V

Agora XII

Agora XXII

Agora XXIX

Agora XXXIII

Akarca 1952

Anderson-Stojanović 1987

$A v P \mathrm{XII}$

Baldiran 1999

Berlin 1997

Bilde - Poulsen 2008

Boulter 1963

Bruneau 1970a

Bruneau 1970b

Bucovala 1967

Civelek 2001

Civelek 2008

Corinth VII
H. S. Robinson, Pottery of the Roman Period: Chrononology. The Athenian Agora V (1959).

B. A. Sparkes - L. Talcott, Black and Plain Pottery of the $6^{\text {th }}$, $5^{\text {th }}$ and $4^{\text {th }}$ Centuries B.C. The Athenian Agora XII (1970).

S. I. Rotroff, Hellenistic Pottery: Athenian and Imported Moldmade Bowls. The Athenian Agora XXII (1982).

S. I. Rotroff, Hellenistic Pottery: Athenian and Imported Wheelmade Table Ware and Related Material. The Athenian Agora XXIX, Part 1 (1997).

S. I. Rotroff, Hellenistic Pottery: The Plain Wares. The Athenian Agora XXXIII (2006).

A. Akarca, "Mylasa'da HellenistikBir Mezar", Belleten 16, 1952 , 367-398.

V. R. Anderson-Stojanovic, "The Chronology and Function of Ceramic. Unguentaria”, $A J A$ 91, 1987, 105-122.

K. Nohlen - W. Radt, Kapikaya, Ein Felsheiligtum bei Pergamon. AvP XII (1978).

A. Baldiran, "Stratonikeia'dan Unguentariumlar", Selcuk Üniversitesi Sosyal Bilimler Enstitüsü Dergisi 4, 1999, 335-356.

A. Berlin, Tell Anafa II: I, The Hellenistic and Roman Pottery: The Plain Wares (1997).

P. G. Bilde - B. Poulsen, The Temple of Castor and Pollux II, 1. The finds (2008).

C. G. Boulter, "Graves in Lenormant Street, Athens", Hesperia 32, 2, 1963, 113-137.

P. Bruneau, "Tombes d'Argos”, BCH 94, 1970, 437-531.

P. Bruneau, Recherches sur les cultes de Délos à l'époque bellénistique et à l'époque impériale (1970).

M. Bucovala, Necropole Elenistice La Tomis (1967).

A. Civelek, Tralleis Nekropolisi Buluntular Isı̆ğnda Hellenistik ve Roma Dönemi Seramiği. Ege Üniversitesi, Sosyal Bilimler Enstitüsü (Unpublished PhD Thesis) (2001).

A. Civelek, "Terra Sigillata, Sinter Astarlı Seramikler", ASanat 128, 2008, 57-62.

G. R. Edwards, Corinthian Hellenistic Pottery. Corinth VII, 3 (1975). 
Corinth XIII
Daremberg - Saglio 1963

Dotterweich 1999

Dündar 2006

Edwards 1959

Erol 2004

FiE IX 2/2

FiE IX/3

Forti 1962

Gassner 1997

Goldman 1940

Guz-Zilberstein 1995

Gürler 1994

Hägg - Fossey 1980

Hausmann 1996

Hayes 1972
C. W. Blegen - H. Palmer - R. Young, The North Cemetery. Corinth XIII (1964).

C. Daremberg - E. Saglio, Dictionnaire des Antiquités Grecques et Romaines (1963).

U. Dotterweich, Unguentarien mit kuppelförmiger Mündung aus Knidos. Knidos-Studien Band I (1999).

E. Dündar, Hellenistik ve Roma Dönemleri Patara Unguentariumlar. Adnan Menderes Universitesi, Sosyal Bilimler Enstitüsü, (Unpublished Master's Thesis) (2006).

G. R. Edwards, "The Gordion Campaign of 1958: Preliminary Report”, AJA 63, 3, 1959, 263-268.

D. Erol, Tralleis Kenti Ką̧larnnda Ele Geçen Baskill Terra Sigillata. Adnan Menderes Üniversitesi, Sosyal Bilimler Enstitüsü, (Unpublished Master's Thesis) (2004).

V. Mitsopoulos-Leon, Die Basilika am Staatsmarkt in Ephesos Kleifunde. 1. Teil: Keramik hellenistischer und römischer Zeit. FiE IX 2/2 (1991).

R. Meriç, Späthellenistisch-römische Keramik und Kleinfunde aus einem Schachtbrunnen am Staatsmarkt in Ephesos. FiE IX/ 3(2002).

L. Forti, "Gli unguentari del primo periodo ellenistico", RendNap 37, 1962, 143-157.

V. Gassner, Das Südtor der Tetragonos-Agora. Keramik und Kleinfunde. FiE XIII 1, 1 (1997).

H. Goldman, "The Acropolis of Halae", Hesperia 9, 1940, 381514.

B. Guz-Zilberstein, "The typology of the Hellenistic Coarse Ware and Selected Loci of the Hellenistic and Roman Periods", in: A. Belfer-Cohen - A. Ben-Tor - Y. Tsafrir (eds.), Excavations at Dor, Final Report Volume I B, Areas A and C: The Finds (1995) 289-434.

B. Gürler, Metropolis’in Hellenistik Dönem Seramiği. Ege Universitesi Sosyal Bilimler Enstitüsü (Unpublished PhD Thesis) (1994).

I. Hägg - J.M. Fossey, The Hellenistic Nekropolis and Later Structures on the Middle Slopes. 1973-1977. Acta Universitatis Upsaliensis, Boreas 4:4 (1980).

U. Hausmann, Hellenistische Keramik. OF XXVII (1996).

J. W. Hayes, Late Roman Pottery (1972). 
Hayes 1975

Hayes 1976

Heimberg 1982

Isings 1957

Kerameikos IX

Khairy 1980

Kurtz - Boardman 1971

Labraunda II.1

Lapp 1961

Metzger 1969

Myres 1914

Okunak 2005

Ölmez 2000

Özgan 1982

Pemberton 1985

Pfrommer 1985

Rotroff 1984

Rotroff - Oliver 2003

Samothrace 11

Schlörb-Vierneisel 1966

Schmaltz 1994
J. W. Hayes, Roman and Pre-Roman Glass in the Royal Ontario Museum (1975).

J. W. Hayes, Roman Pottery in the Royal Ontario Museum (1976).

U. Heimberg, Die Keramik des Kabirions (1982).

C. Isings, Roman Glass from Dated Finds (1957).

U. Knigge, Der Südbügel. Kerameikos IX (1976).

N. I. Khairy, "Natatean Piriform Unguentaria", BASOR 240, 1980, 85-91.

D. Kurtz - J. Boardman, Greek Burial Customs (1971).

P. Hellström, Pottery of Classical and Later Date Terracotta Lamps and Glass. Labraunda Vol. II, Part 1 (1965).

P. W. Lapp, Palestinian Ceramic Chronology 200 B.C.-AD. 70 (1961).

I. R. Metzger, Die Hellenistische Keramik in Eretria (1969).

J. L. Myres, Handbook of the Cesnola Collection of Antiquities from Cyprus, Metropolitan Museum of Art (1914).

M. Okunak, Hierapolis Kuzey Nekropolü (159D Nolu Tümülüs) Anıt Mezar ve Buluntuları. Pamukkale Universitesi, Sosyal Bilimler Enstitüsü (Unpublished Master's Thesis) (2005).

F. Ölmez, Tralleis Nekropolünden Bir Mezar ve Buluntular. Adnan Menderes Universitesi, Sosyal Bilimler Enstitüsü, (Unpublished Master's'Thesis) (2000).

R. Özgan, Yunan ve Roma Devri Tralleis Heykelttraşlğg (1982).

E. G. Pemberton, "Ten Hellenistic Graves in Ancient Corinth", Hesperia 54, 3, 1985, 271-307.

M. Pfrommer, "Milet 1983-1984. Klassische und hellenistische Keramik aus dem Heroon 111", IstMitt 35,1985, 39-58.

S. I. Rotroff, "The Origins and Chronology of Hellenistic Gray Unguentaria”, AJA 88, 1984, 258.

S. I. Rotroff- A. Oliver Jr., The Hellenistic Pottery from Sardis. The Finds Through 1994 (2003).

E. B. Dusenbery, Necropoleis: The Necropoleis and catalogues of burials and Catalog of objects by categories. Samothrace 11 (1998).

B. Schlörb-Vierneisel, "Eridanos-Nekropole", $A M$ 81, 1966, 1135.

B.Schmaltz, "Kaunos 1988-1991”, AA, 1994, 185-232. 
Stern 2008

Şimșek - Duman 2007

Takaoğlu 2006

Tarsus I

Thompson 1934

Thompson 1971

Toynbee 1971

Vessberg - Westholm 1956

Wiseman - Mano-Zissi 1976

Yaylalı 2009

Zoroğlu 1986
K. B. Stern, Inscribing Devotion and Death: Archaeological Evidence for Jewish Populations of North Africa (2008).

C. Şimşek - B. Duman, “Laodikeia'da Bulunan Geç Antik Çağ Unguentariumları”, Adalya X, 2007, 285-307.

T. Takaoğlu, "New Lights on the Origins of Eastern Sigillata B Ware", in: T. Takaoğlu (ed.), Anadolu Arkeolojisine Katkılar, 65. Yaşında Abdullah Yaylali'ya Sunulan Yazılar (2006), 263-265.

F. F. Jones, "The Pottery", in: H. Goldman (ed.), Excavations at Gözliu Kule, Tarsus. Volume I. The Hellenistic and Roman Periods (1950) 149-296.

H. A. Thompson, "Two Centuries of Hellenistic Pottery", Hesperia $3,1934,311-480$.

D. B. Thompson, An Ancient Shopping Center (1971).

J. M. C. Toynbee, Death and Burial in the Roman World (1971).

O. Vessberg - A.Westholm, The Swedish Cyprus Expedition, Vol. IV, The Hellenistic and Roman Periods in Cyprus IV, 3 (1956).

J. R. Wiseman - D. Mano-Zissi, "Stobi: A City of Ancient Macedonia", JFieldA 3 (3), 1976, 269-302.

A.Yaylalı, "2007 Yılı Tralleis Antik Kenti Kazı Çalışmaları”, KST 30, 3. Cilt, 2009, 17-40.

L. Zoroğlu, "Kelenderis Mezar Buluntuları", AnadoluAraş X, 1986, 455-466. 


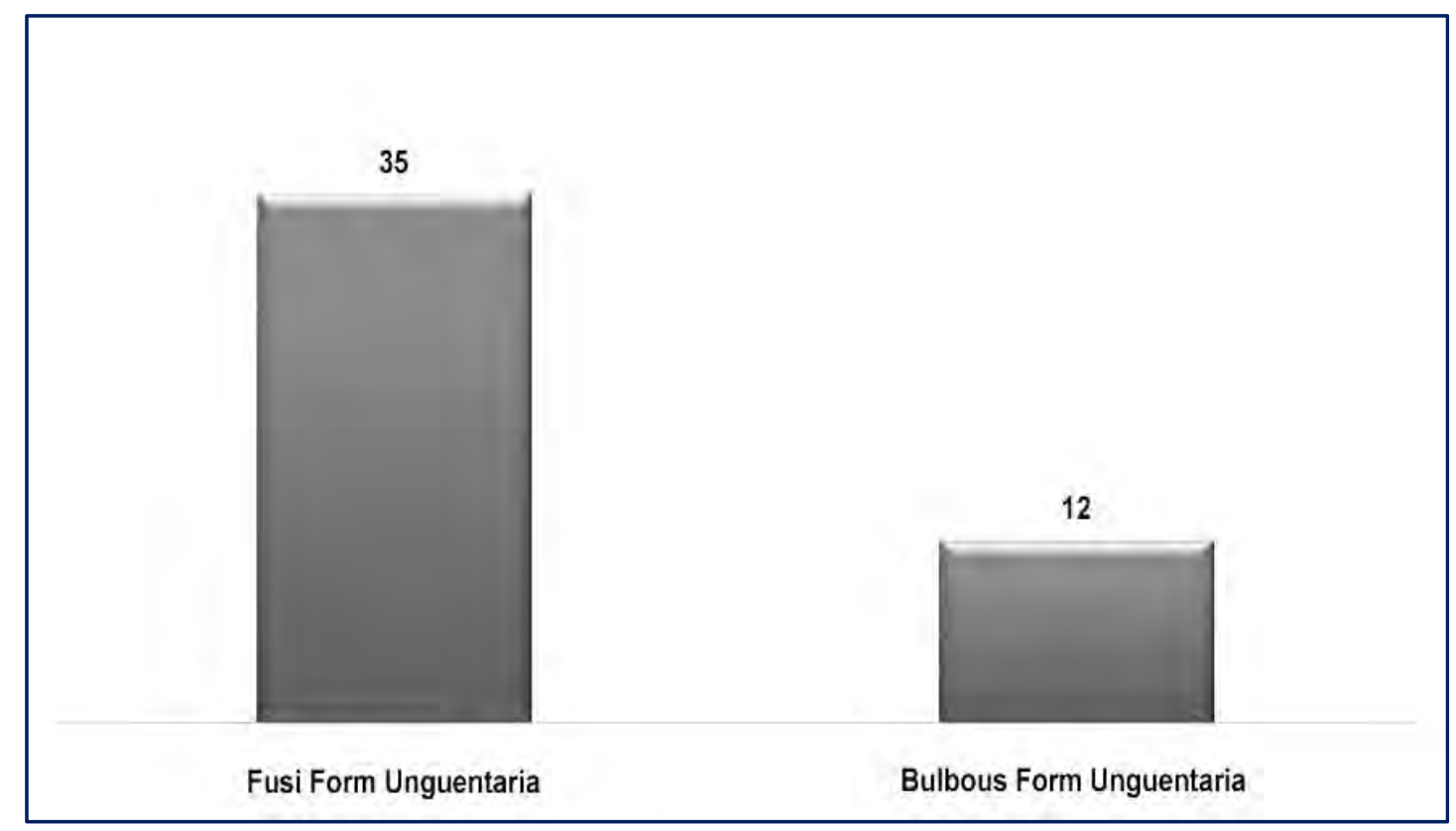

Graphic 1

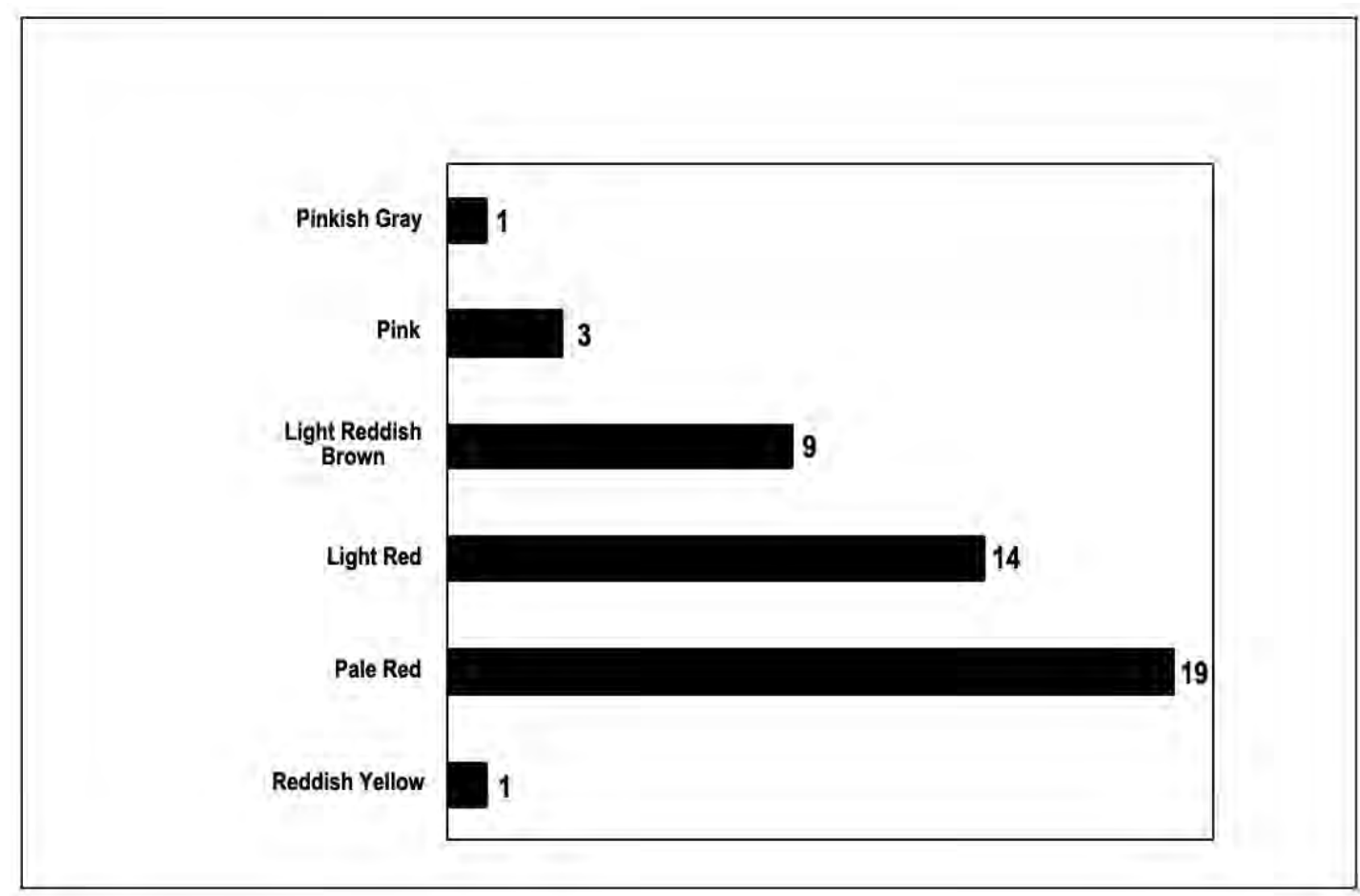

Graphic 2 


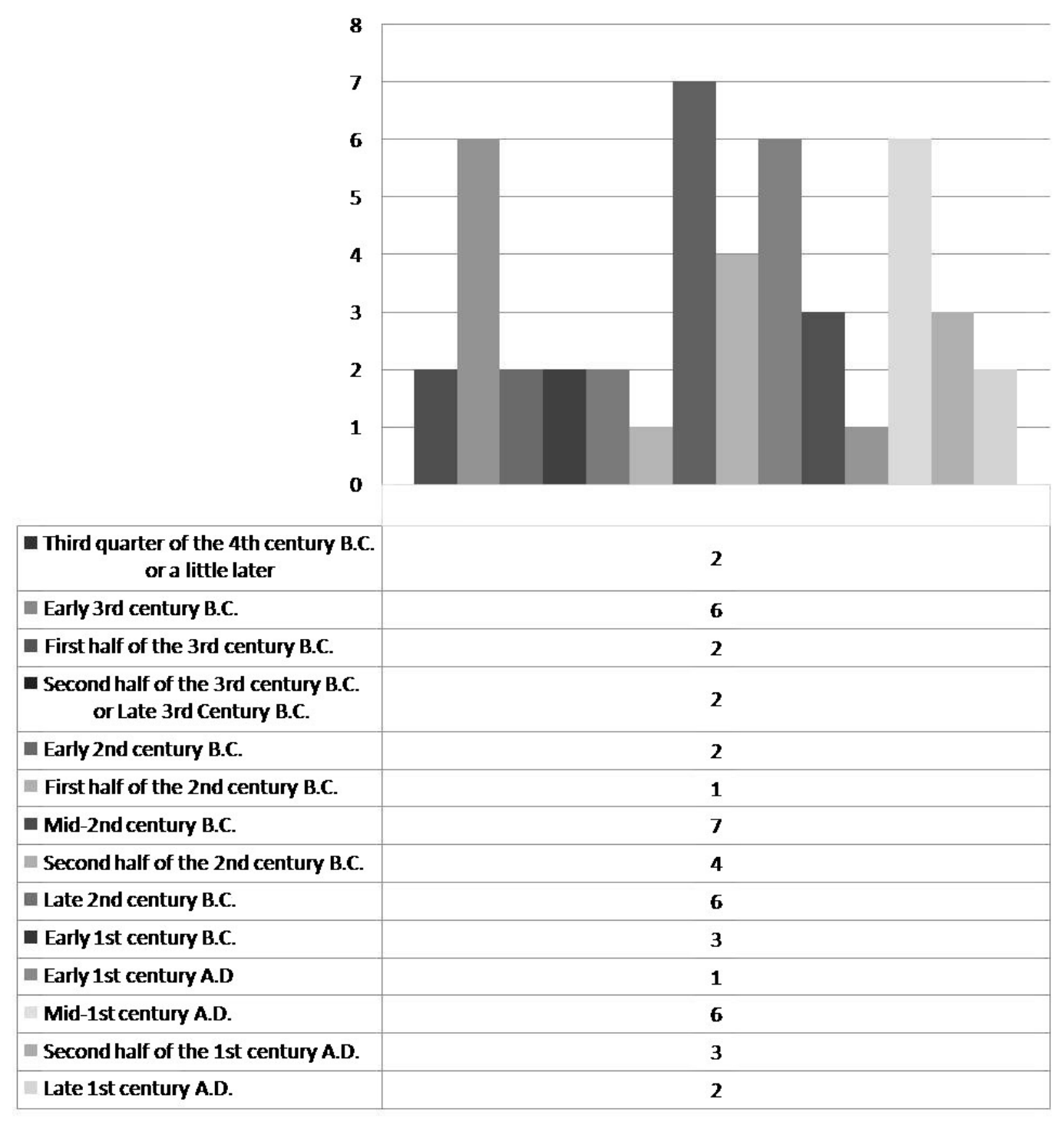

Graphic 3 


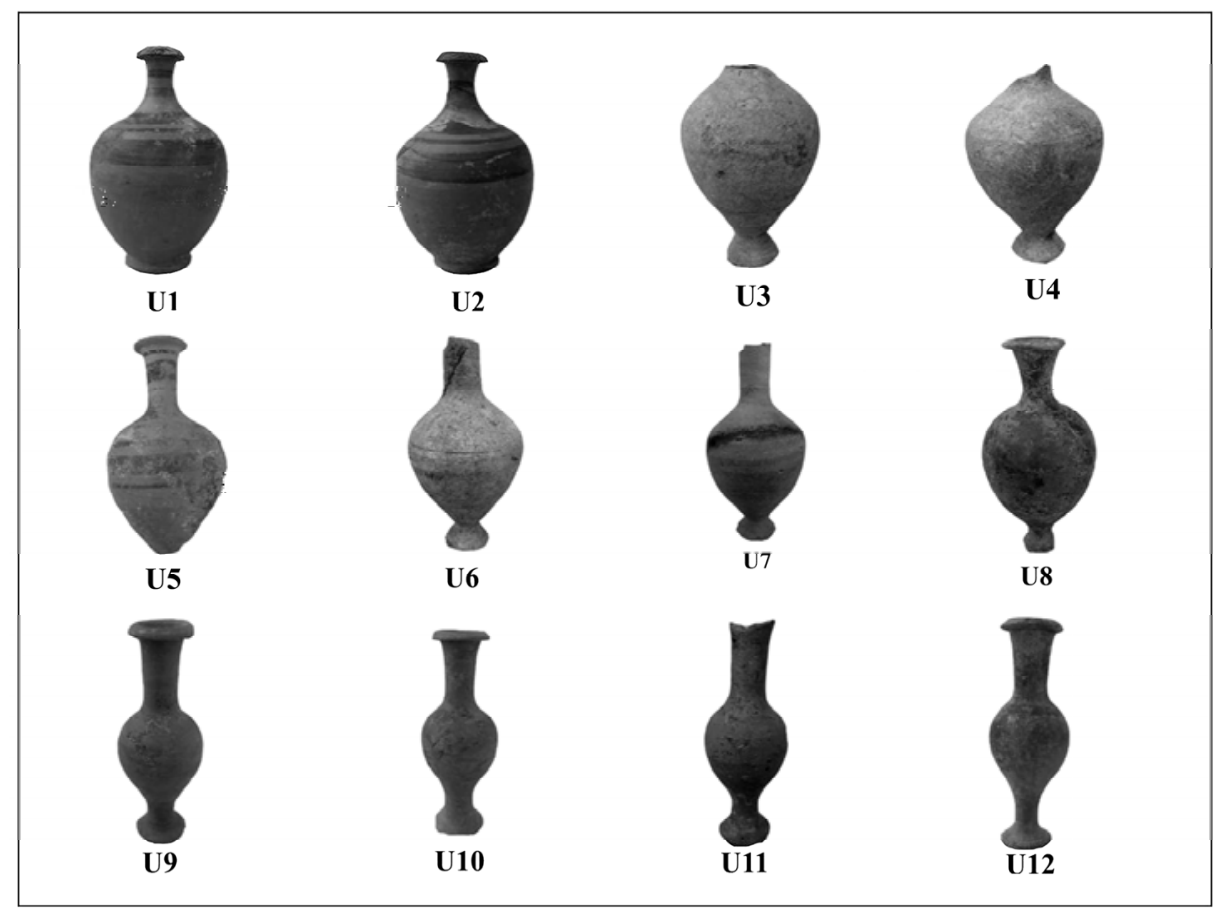

Figure 1

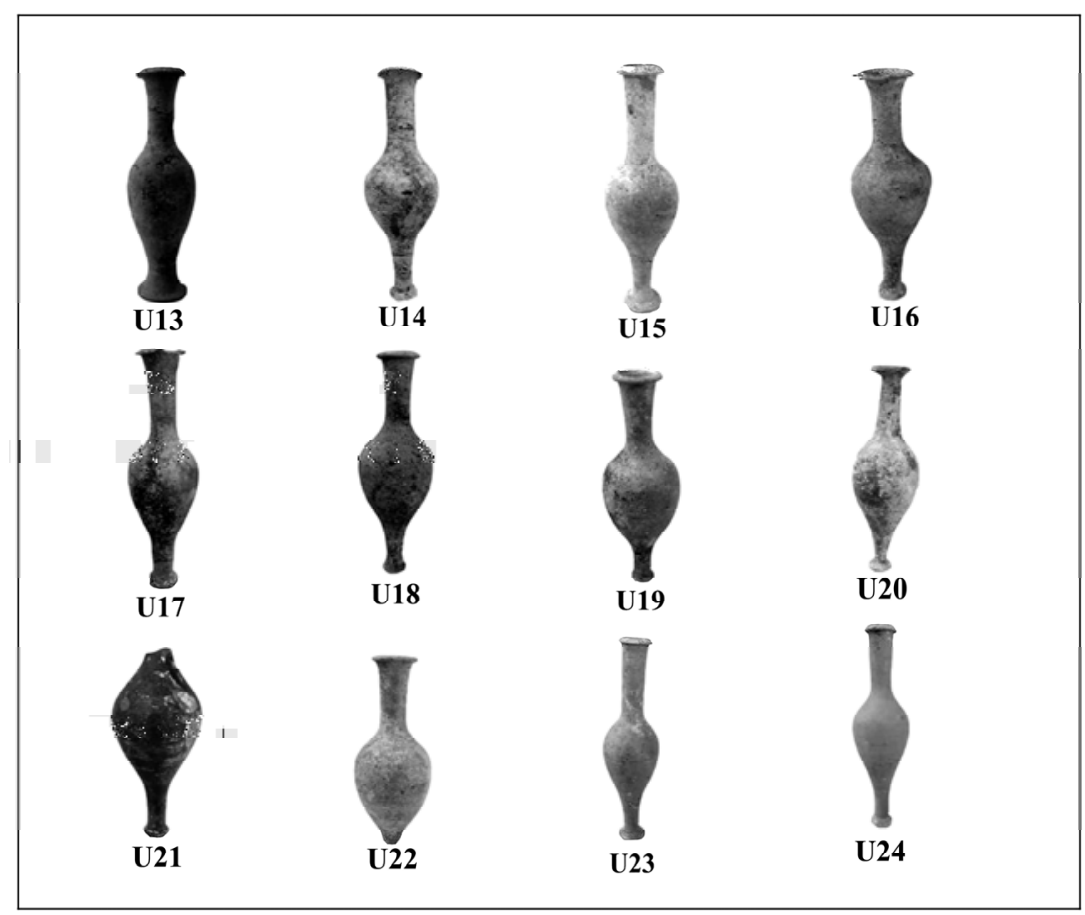

Figure 2 


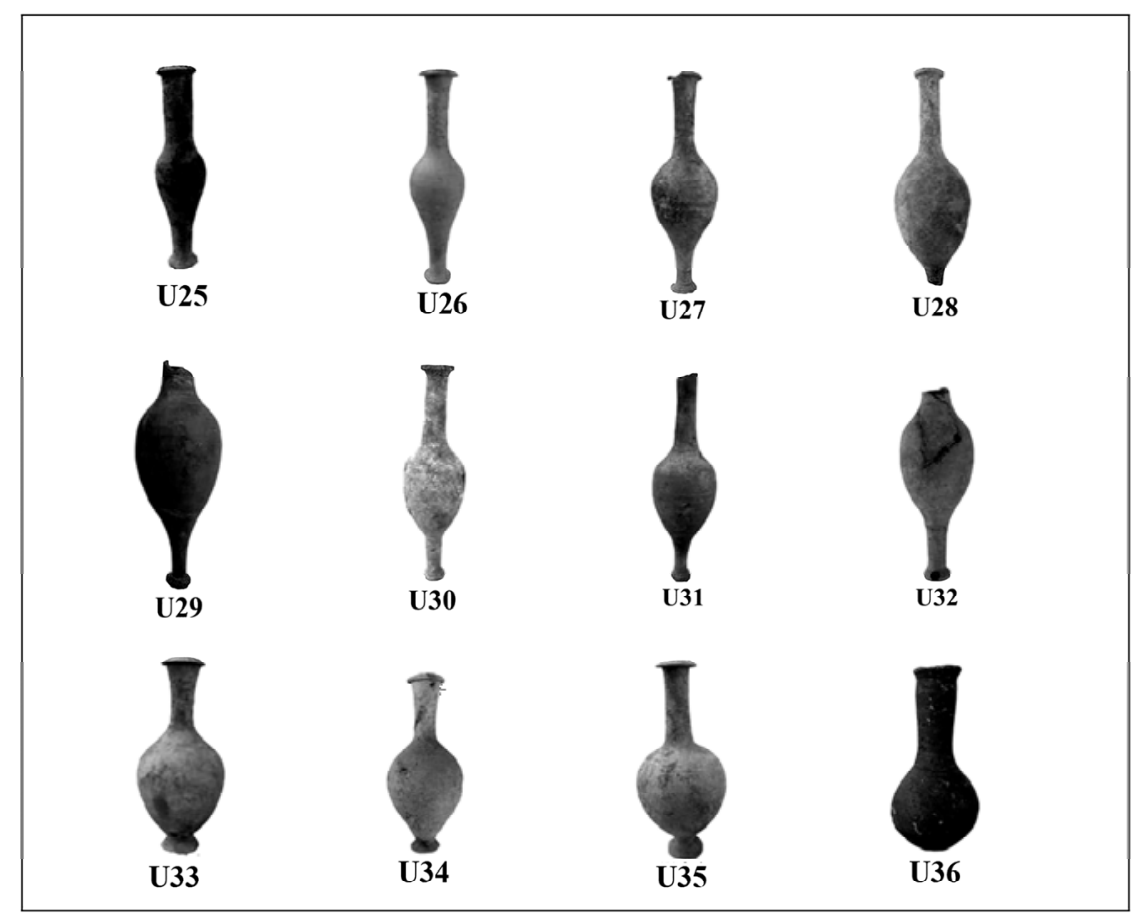

Figure 3

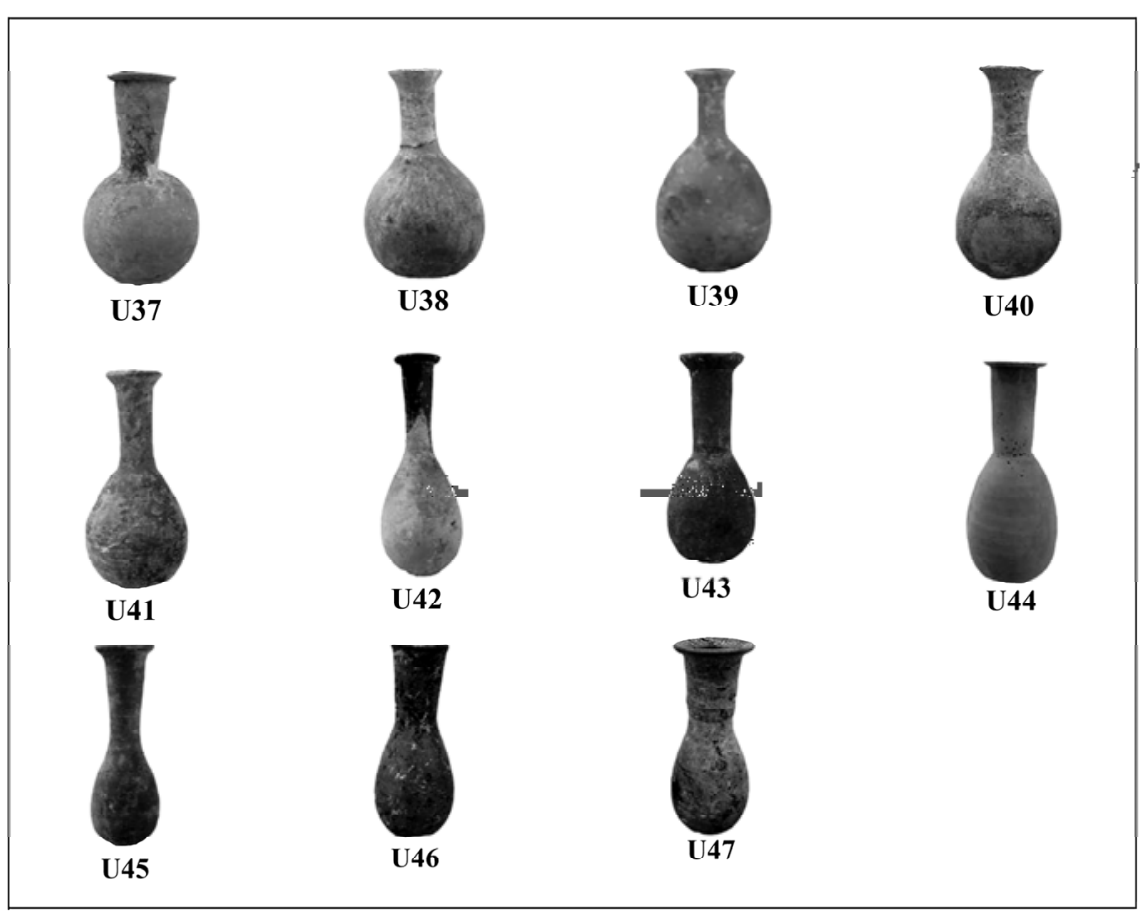

Figure 4 